Published as: Kellens, W., Terpstra, T., Schelfaut, K., De Maeyer, P., 2013. Perception and communication of flood risks: A literature review. Risk Analysis. 33 (1), 24-49.

\title{
PERCEPTION AND COMMUNICATION
}

\section{OF FLOOD RISKS:}

\section{A SYSTEMATIC REVIEW OF}

\section{EMPIRICAL RESEARCH}

dr. Wim Kellens ${ }^{1}$, dr. ir. Teun Terpstra ${ }^{2}$, prof. dr. Philippe De Maeyer ${ }^{3}$

\author{
${ }^{1,3}$ Ghent University \\ Department of Geography \\ Krijgslaan 281, S8 (WE12) \\ B-9000 Gent, Belgium \\ ${ }^{2}$ HKV Lijn in Water \\ Postbus 2120 \\ 8203 AC Lelystad, Nederland \\ ${ }^{1}$ Corresponding author \\ email:wim.kellens@ugent.be \\ tel: +3292644696 \\ fax: +329264 4985
}




\begin{abstract}
Flood hazards are the most common and destructive of all natural disasters. For decades, experts have been examining how flood losses can be mitigated. Just as in other risk domains, the study of risk perception and risk communication has gained increasing interest in flood risk management. Because of this research growth, a review of the state of the art in this domain is believed necessary. The review comprises 57 empirically based peer-reviewed articles on flood risk perception and communication from the Web of Science and Scopus databases. The characteristics of these articles are listed in a comprehensive table, presenting research design, research variables, and key findings. From this review, it follows that the majority of studies are of exploratory nature and have not applied any of the theoretical frameworks that are available in social science research. Consequently, a methodological standardization in measuring and analyzing people's flood risk perceptions and their adaptive behaviors is hardly present. This heterogeneity leads to difficulties in comparing results among studies. It is also shown that theoretical and empirical studies on flood risk communication are nearly nonexistent. The paper concludes with a summary on methodological issues in the fields of flood-risk perception and flood-risk communication and proposes an agenda for future research.
\end{abstract}

\title{
Key words
}

flood risk, risk perception, risk communication, literature review 


\section{INTRODUCTION}

Flood hazards are a serious threat to the economic and social structures of our society. Each year, floods claim approximately 20,000 lives and adversely affect at least 20 million people worldwide, mostly because of the homelessness resulting from flood events. ${ }^{\text {(cf. } 1)}$ Recent studies have indicated that losses from flood hazards are expected to increase in coming years. This prognosis is mainly based on the predicted impacts of climate change. ${ }^{(2)}$ In many countries, however, flood vulnerability is also expected to increase as a consequence of population growth and spatial expansion. ${ }^{(3)}$ Around the world, flood-risk experts and decision makers face the challenge of finding techniques and measures to effectively cope with these hazards. In order to assess the negative impact of flood hazards, experts have gradually adopted a risk-based approach that focuses on the probability of events and the magnitude of negative consequences. ${ }^{(4)}$ While this technical approach deals with "objective" risk assessment, a substantial group of researchers have concentrated on the "subjective" aspects of flood risk, which determine people's risk perception. Several researchers recognize that flood-risk management is shifting from a primarily objective approach to an integrated approach with attention to social aspects such as improving flood preparedness and response. ${ }^{(5,6)}$ As such, the need to integrate lay knowledge into measures to prevent, mitigate, and deal with risk is a relatively new field of research. ${ }^{(7)}$ Risk communication is becoming increasingly promulgated as an essential measure to fulfill these needs. ${ }^{(8)}$

Previous articles have reviewed the general evolution of risk perception and communication, ${ }^{(9)}$ comparative studies in risk perception, ${ }^{(10)}$ and risk communication to the public. ${ }^{(11)}$ Up to now, however, no review article has covered the findings of risk perception and risk communication in flood-risk research. As a result of the increasing attention to flood-risk mitigation and the application of risk perception and risk communication in this regard, an overview of the state of the art in these domains is believed necessary.

This review paper is organized as follows. Section 2 presents background information on the origins of risk perception and risk communication. Sections 3 to 6 provide an overview and discussion of a 
set of empirically based peer-reviewed articles in the domains of flood-risk perception and flood-risk communication. Attention is successively given to the selection of the studies, general trends, the research designs that have been used (i.e., study area, flood type, and survey methodology), the theories that have been applied and developed, and the empirical findings that have resulted. Finally, Section 7 provides a compact discussion and proposes an agenda for future research in the domain.

\section{BACKGROUND}

\subsection{Risk perception}

Research on risk perception began in the 1940s, when Gilbert White published his groundbreaking thesis on human adjustments to floods in the United States. ${ }^{(12)}$ White found that people's past experience with floods directly influenced their behavior when they were under threat from a possible flood. With his work, White pioneered the way for research on the human dimension of risk in multihazard environments. ${ }^{(13,14)}$ In the 1960s, risk perception appeared on the stage of political agendas since it was considered a main determinant of public opposition to new technologies, in particular nuclear technology. Based on the analysis of historical data, Starr ${ }^{(15)}$ discovered a systematic relation between the acceptance of technological risks and the perception of costs and benefits from these technologies. It seemed that society accepted risks to the extent that they were associated with benefits. ${ }^{(16)}$ While this method of exploring revealed preferences resulted in new insights, questions arose about its objectivity, since findings are strongly influenced by the interpretation of the researcher. ${ }^{(17)}$ In subsequent decades, risk-perception research evolved to psychological experiments and public surveys, in which people's perception could be assessed with expressed preferences. This evolution led to the development of several theories and approaches, some of which will be illustrated in more detail in Section 6. 


\subsection{Risk communication}

Covello et al. ${ }^{(18)}$ define risk communication as any purposeful exchange of information about health or environmental risks between interested parties. Trettin and Musham $^{(19)}$ clarify these parties as individuals, groups, or organizations. Risk communication covers a wide range of activities, such as stimulating interest in environmental health issues, increasing public knowledge, influencing attitudes and behavior of people, acting in situations of emergency or crises, aiding in decision making, and assisting in conflict resolution. ${ }^{(20)}$ In his White Paper on Risk Governance, Renn ${ }^{(8)}$ underlines the importance of adjusting risk communication to the specific needs of the people. In this way, people are facilitated to judge their own risk situation and to make informed decisions according to preparedness and personal safety measures. Effective communication, or the absence of it, may have a major bearing on how well people are prepared for a disaster. ${ }^{(21)}$

According to the definition of Covello et al., ${ }^{(18)}$ risk communication should aim for a bidirectional exchange of information. However, this bidirectional exchange has not always been considered the key to effective risk communication. The early rationale for risk communication research derived from the identified distinction between the scientific way to assess risk (based on calculations of probability and estimated "loss") and the lay people approach, which tended to over- or underestimate risk. ${ }^{(20)}$

Over the last two decades, risk communication has gradually evolved to a two-way communication process in which both the public and the risk managers are expected to engage in the social learning process. ${ }^{(8)}$ Today, it is widely recognized that public values and preferences must be included in risk assessment and management. ${ }^{(20,22)}$ Emphasis has shifted from a pedagogical approach to deliberation, dialogue, and public participation. The normative theory of communicative rationality advocates this dialogue between actors who are willing to listen to each other and who are open to changing their minds and positions on a certain issue depending on how the deliberative process unfolds. ${ }^{(23)}$ To obtain a successful dialogue, mutual trust is needed between the actors. ${ }^{(24)}$ However, as Pidgeon ${ }^{(25)}$ mentioned, "Trust is hard to gain, but easy to lose." 


\section{SELECTION OF STUDIES}

During November-December 2010, an extensive literature search was conducted on the electronic online databases Web of Science (http://www.isiknowledge.com) and Scopus (http://www.scopus.com). Web of Science is a well-regarded database, which-according to the database publisher-provides seamless access to multidisciplinary coverage of more than 10,000 high-impact journals in the sciences, social sciences, and arts and humanities, as well as international proceedings coverage for more than 120,000 conferences. Scopus is a relatively new but rapidly expanding database, and claims to be the largest abstract and citation database, containing approximately 17,000 peer review journals.

Four standards were applied to our literature selection: (1) The work is peer-reviewed in an international journal; (2) The research is based on empirical data that relates to citizens, or at least partly to citizens; (3) The research is applied to flood risks in general or to a specific type of flood risk (e.g., river, flash, coastal, and so on); and (4) The public perception of, or the public attitude toward, flood risks is measured (either qualitatively or quantitatively), or specific attention is given to the communication of these risks. In order to find as many articles as possible in this context, the following search key was designed:

(flood* OR hazard*) AND (perception* OR perceiv* OR attitud*OR communicat*)

The use of an asterisk enabled finding articles with "flood," "floods," or "flooding"; "perception" or "perceived"; "communication" or "communicated"; and "attitude" or "attitudinal" in their title, keywords, or abstract. The word "hazard" was used to capture also articles that would refer to floods as "natural hazard" or "environmental hazard." The gross number of articles found in both databases (Web of Science and Scopus) was 642 (269 and 373, respectively). By removing 105 duplicates, the net number was reduced to 537 articles. However, it was clear from the title alone that about 80 percenet of these articles did not fit the four established standards. Although the words "floods," 
"perception," or "communication" were used in these articles, their meaning was unrelated to this study's social/psychological perspective (e.g., "The chemical expression of biotic and abiotic processes occurring in the Amazonian floodplains can be particularly perceived during falling waters") and, in some cases, the word "flood" actually meant something totally different (e.g., "Flooding is a commonly used technique for network resource and topology information dissemination in the data communication networks"). Deleting these unintended hits further reduced the number to 114 articles. In a final step, the authors independently and carefully reviewed all 114 abstracts by applying the four selection standards. The authors independently decided that 49 papers met with all four selection standards and that 45 papers should be removed because they failed to meet one or more of the four selection standards. Hence, the authors agreed on 82 percent of the papers. The corresponding level of inter-rater agreement expressed by Cohen's Kappa was therefore 0.64, indicating a substantial agreement among the authors. The remaining 20 papers were discussed before a decision was made. Some abstracts did not contain sufficient information for these selection criteria, so full papers were then analyzed. Twenty-five articles were omitted because they were not based on empirical data (selection standard 2). Another thirty-seven articles were removed from the list since they did not measure (neither qualitatively nor quantitatively) the public perception of flood risks (selection standard 4). Strict implementation of selection standard 4 resulted in the omission of a set of articles on mental health issues and psychological impacts (e.g., post-traumatic stress syndrome) resulting from flood experiences. Fifty-two articles remained after this in-depth review. Eventually, the set of articles was extended with two recently published articles (which were not yet taken up in Web of Science or Scopus at the time of the literature search) and three articles in press. As such, the final selection comprised 57 articles.

Table I in the appendix presents this selection of papers with the following characteristics: (1) author and year; (2) research design (including study area and flood type, number and type of respondents, survey method, and the theory that was applied); (3) research variables (including risk-perception variables $[\mathrm{RP}]$, behavioral variables regarding mitigation and preparedness $[\mathrm{BV}]$, and other important 
variables [OIV]); and (4) key findings of each study. The following sections each discuss one or more of these columns in more detail.

\section{GENERAL TRENDS}

With regard to the publication year, a marked increase is observed in the number of studies on floodrisk perception in recent years. Only eight of the 57 studies were published before 2005; as many as 49 studies have been published since 2005 .

Figure 1 presents the number of publications by journal. The 57 studies were published in 24 different journals. Leading journals in the domain of flood-risk perception are Risk Analysis (15 publications), Natural Hazards (8 publications), and Natural Hazards and Earth System Sciences (6 publications). Journal of Risk Research and Environmental Hazards each have three publications. The other nineteen journals (79 percent) have published only one or two studies in the field. This shows that perception research on flood risks is more supported by journals related to environmental risks and hazards than by journals related to psychological or health issues.

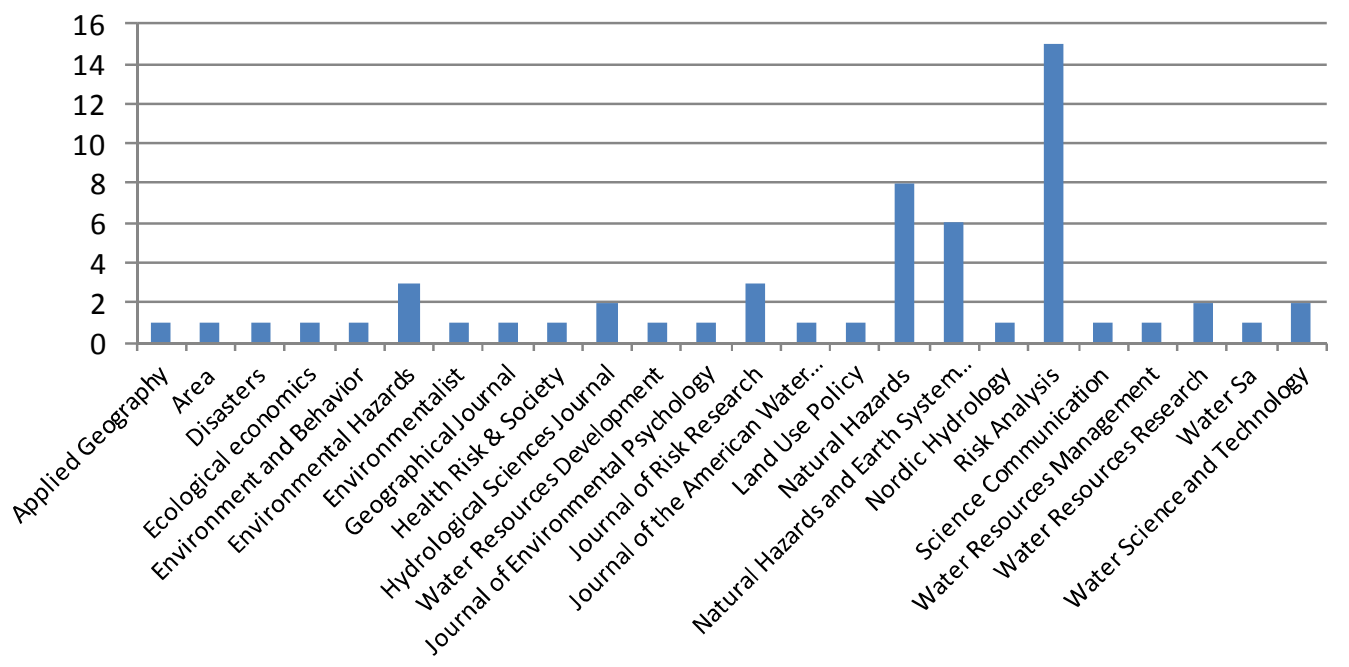

Figure 1 Number of publications by journal 


\section{RESEARCH DESIGN}

\subsection{Study area and flood type}

The study of flood-risk perception is paramount in the Western world. Europe is well represented by 34 studies, followed by North America (10 including Puerto Rico) and Asia (10). In Europe, most studies have their study area in the Netherlands (7), Germany (7), United Kingdom (4), Spain (3), and Switzerland (3). North America counts research only from the United States (8) and Puerto Rico (2). In Asia, most studies come from Japan (4) and Taiwan (3). The Southern Hemisphere is strongly underrepresented in the literature. Our search revealed only two studies that were conducted in Africa (Nigeria and South Africa); there were none in South America and Oceania. The only study with an international study area is Krasovskaia et al., ${ }^{(26)}$ with a focus on the countries surrounding the North Sea (Germany, the Netherlands, Norway, Sweden, and United Kingdom).

Regarding flood type, it should be noted that it was often difficult to identify the type under study. Some studies clearly mentioned the flood type, but in other studies, the flood type could be determined only from the study area. Some researchers focused on just one type, others explored multi-flood types. In a number of studies (15), it was not possible to determine any flood type. In Table I, a primary distinction is made between river, coastal, and flash floods. Most studies in floodrisk perception research deal with river floods (26). Studies on flash floods (9) and coastal floods (8) form a smaller group. Three single studies examined specific flood types, i.e., groundwater flooding, ${ }^{(27)}$ sewage flooding, ${ }^{(28)}$ and muddy floods. ${ }^{(29)}$ While some of these flood types involve a specific cause (e.g., sewage flooding as a consequence of sewerage malfunction), general flood causes such as rainfall, storm surge, or typhoon/hurricane are often not reported. Seven studies examine other hazards related to flood risks, such as landslides, ${ }^{(30-32)}$ earthquakes, ${ }^{(33)}$ and chemical releases. ${ }^{(34)}$ 


\subsection{Survey methods}

All but two studies conducted a cross-sectional survey on respondents. This study design involves observation of all of a population, or a representative subset, at a defined time. ${ }^{(35)}$ Keller et al. ${ }^{(36)}$ and Terpstra et al. ${ }^{(37)}$ have used (quasi-)experimental designs, in which respondents are surveyed under controlled circumstances. Choosing the appropriate survey method encompasses numerous decisions regarding questionnaire characteristics and sampling technique.

\subsubsection{Questionnaire characteristics}

In order to measure or grasp the perception, attitude, or behavior of people, a well-developed questionnaire is of paramount importance. While it is encouraged to reuse approved or standardized questionnaires in surveys, ${ }^{(14,38)}$ it seems that most researchers in flood-risk perception studies develop their own questionnaires ${ }^{(\text {e.g. } 3,13,29,39-45)}$ or adapt questionnaires from other work to fit their specific needs. ${ }^{\text {(e.g., }}$ 37,46,47-49) Few studies report that their questionnaires had been tested, for example by focus groups, ${ }^{(40)}$ households, ${ }^{(50)}$ or experts. ${ }^{(41,51,52)}$ Even in theoretically based research, studies make (small) adaptations to the questionnaire. For example, Ge et al. ${ }^{(33)}$ and Lin et al. ${ }^{(31)}$ employed the Psychometric Paradigm for their research, yet the items applied to measure risk perception differ between both studies (cf. paragraph 6.1).

\subsubsection{Sampling technique}

With regard to delivery method, Bird ${ }^{(14)}$ distinguishes between self-administered and administered methods. Among the self-administered methods, questionnaires can be distributed by either mail or email. Despite the increasing interest in online questionnaires, (e.g., 5,6,58,59) mail-distributed questionnaires remain the most popular self-administered method. ${ }^{\text {(e.g., 3,41,48,50,60) }}$ The administered method relies on interviews, either face-to-face or by telephone. Although these methods ensure high response rates, they are very labor-intensive and therefore generally less advantageous for surveying 
large samples. Nonetheless, some researchers have obtained samples from more than 500 respondents using computer-aided telephone survey software (CATI) such as VOXCO. ${ }^{(27)}$ A minority of the studies $^{(37,43,45,52,55,61)}$ have used focus groups. This method is particularly interesting for retrieving qualitative responses.

In order to obtain a representative sample, most studies have utilized a probability method, such as simple random, ${ }^{(29,53)}$ stratified sampling, ${ }^{(44)}$ or cluster sampling. ${ }^{(53)}$ Only two studies ${ }^{(54,55)}$ have employed a non-probability method, in which it is not the aim to create a statistically representative sample but rather to provide adequate coverage of a certain criterion (e.g., only flood victims). Despite the importance of the sampling method regarding representativeness of the sample, more than 40 percent of the studies fail to report it. Among the studies that have reported their sampling method, the majority (65 percent) have used a random-sampling method.

\subsection{Sample characteristics}

Finally, Table I depicts the number of respondents or sample size per study. If more than one delivery method is used, the sample size is indicated per method, unless no information is provided in the study. Twelve studies had less than 100 respondents, 14 studies had sample sizes of 101 to 400 , and as many as 30 studies had more than 400 respondents. One study ${ }^{(49)}$ failed to report the sample size. As Lindell and Perry ${ }^{(38)}$ indicate, studies with $N>400$ have excellent power to produce significant results that are also representative for the total population. The correct sample size depends on the desired confidence level, the degree of reliability, and the degree of validity. ${ }^{(59)}$ However, larger sample size invokes lower confidence limits, so a trade-off must be made between precision (reproducibility) and accuracy (closeness to the real value). ${ }^{(62)}$

Regarding the target group, most studies simply address the general public, whether or not located in a flood-prone area. ${ }^{(\text {e.g. }}{ }^{7,40)}$ Some studies specify the target group, such as farmers, ${ }^{(29)}$ homeowners, ${ }^{(6)}$ and flood victims. ${ }^{(56)}$ Other studies also survey non-public groups, such as local authorities ${ }^{(33)}$ and decision makers. ${ }^{(57)}$ 


\section{THEORIES AND EMPIRICAL FINDINGS}

In this section, an overview is presented of the theories that have been employed in flood-riskperception research and the most important empirical findings that have resulted from them. Main distinction is made between studies that examined how people perceive flood risks (cf. paragraph 7.1) and studies that observed people's behavior in response to their exposure to flood risk (cf. paragraph 7.2). The few empirical studies that examined flood-risk communication are discussed in paragraph 7.3. This section ends with an overview of important variables that have not been included in formal theories or tested as such (paragraph 7.4).

\subsection{Examining risk perceptions}

\subsubsection{Psychometric Paradigm}

An influential and popular theoretical framework in risk-perception research is the Psychometric Paradigm. This theory, introduced by Fischhoff et al. ${ }^{(63)}$ and Slovic, ${ }^{(64)}$ attempts to quantify individuals' risk perceptions and attitudes through survey questionnaires. It further assumes that many characteristics of risk perception and their interrelationships can be quantified and modeled. In the questionnaires respondents are asked to express their perceptions on rating scales (expressed preferences) about various characteristics of the risk (e.g., severity and long-term consequences), their personal ability to cope with the risk (e.g., controllability, knowledge), their feelings (e.g., dread), and their attitudes toward risk management (e.g., trust). The quantitative ratings allow comparisons not only between risks (e.g., natural versus technological hazards) but also among specific groups in society (e.g., ethnic groups) and among countries. ${ }^{(10)}$

Applications of the Psychometric Paradigm indicate that flood risk is perceived differently among countries. For instance, mean ratings among a sample of Chinese lay people ${ }^{(33)}$ indicated that flood risk is perceived as an involuntary, uncontrollable, potentially fatal and catastrophic risk that evokes 
high levels of dread, but which is also seen as an "old" risk, fairly well known to both scientist and exposed citizens. In contrast, studies from the Netherlands ${ }^{(37,45)}$ indicate that Dutch citizens are rather fearless with regard to flood risks, although the Dutch generally believe the risk is increasing due to global warming. One factor that is important for explaining such differences is the extent to which people are exposed to floods (e.g., due to differences in public flood protection and personal experiences). Lin et al. ${ }^{(31)}$ found that Taiwanese flood victims, compared with non-victims, perceived more dread, larger flood likelihood and consequences, and less personal control. However, victims and non-victims did not differ in their trust in the governments', experts', and mass media's capabilities to respond to flood crises (see also Ho et al. ${ }^{(30)}$ who reported on the same data). In addition to exposure, differences among countries may be explained by cultural differences or differences in social norms and values among societies. Ge et al. ${ }^{(33)}$ compared risk ratings from Chinese lay people with ratings of American citizens, which were previously reported by Slovic. ${ }^{(64)}$ Although the ratings from the two studies were quite similar for some risks (e.g., nuclear power were in both countries perceived as the number one risk), a comparison on floods could not be made since Slovic's study did not include flood risks (which was perceived as the second highest risk among the Chinese lay people). Yet, such comparisons are much needed in order to gain insight into the role of culture in risk perceptions. Ideally, they should be made within a single study to ensure uniformity in the survey methodology and to avoid large time gaps between the surveys (the time gap between Slovic's and Ge's studies was more than 20 years, which makes direct comparisons between risk ratings questionable).

\subsubsection{Heuristics}

Another influential line of research is known as "heuristics." Heuristics, or simple and efficient rules of thumb, is often used by people to simplify complex problems and to make decisions without using all of their cognitive capacities. Although heuristics can be very helpful in daily life, research has shown that the heuristics are sometimes prone to systematic biases caused by a number of psychological phenomena. Well known are the availability heuristic, the representativeness heuristic, 
and the anchor and adjustment heuristic. ${ }^{(65)}$ A fourth heuristic that is gaining increasingly more attention in flood-risk research is the affect heuristic, ${ }^{(66)}$ which is closely connected with the risk-asfeelings hypothesis. ${ }^{(67)}$ Keller et al. ${ }^{(36)}$ pointed to this heuristic by testing the effect of affect-laden imagery on respondents. The results of their experiments suggested that affect (e.g., fear) is important for successful risk communication. Other researchers, such as Siegrist and Gutscher, ${ }^{(68)}$ Miceli et al., ${ }^{(67)}$ and Terpstra ${ }^{(69)}$, have also acknowledged the significance of affect in perceiving and communicating flood risks.

\subsubsection{Non-theoretical approaches to risk perception}

Although both the Psychometric Paradigm and the heuristics approaches are influential methods in risk-perception research, it seems that the majority of the studies that focus on flood-risk perception do not employ them. The main reason for this finding lies in the explorative nature of most of these studies, which is reflected in the many risk-perception characteristics that have been measured. However, the differences in measurement also suggests there exists no consensus on the type of questions or items that are needed to measure the various aspects of risk perception. As Miceli et al. ${ }^{(67)}$ indicate, flood-risk perception is a complex process that encompasses both cognitive (e.g., likelihood, knowledge, etc.) and affective (e.g., feelings, perceived control, etc.) aspects. Therefore, most studies employ [a different set of] multiple questions or items to measure the various aspects of risk perception. In order to process the items, different methods are applied. Most researchers (e.g., 29) preserve the items as separate variables, but other authors like Miceli et al. ${ }^{(67)}$ or Kellens et al. ${ }^{(48)}$, respectively, use the Partial Credit Model (PCM) and factor analysis to transform several items into one score. However, in some studies, perceived levels of flood risk have been measured by only one question or item. Examples are given in Burningham et al. ${ }^{(61)}$ and Horney et al. ${ }^{(53)}$ 
To structure the measurement of risk perception (RP), Table I classifies five different and frequently used variables or items within non-theoretical perception research: ${ }^{1}$ items related to (1) awareness (or consciousness, e.g., "Are you aware that you live in a flood-prone area?”); (2) affect (or worry, fear, concern, e.g., "Do you feel personally endangered by a flood?"); (3) likelihood (or probability, e.g., "What do you think about the chances of a flood in your neighborhood within the next 10 years?"); (4) impact (or consequences, vulnerability, e.g., "Rate the following statement: A flood will have fatal consequences for me and my family"); and (5) cause (or origin, e.g., "Can you indicate the cause of the flood risk in your neighborhood?"). The items of impact and likelihood are most often employed (respectively, in 23 and 18 studies), followed by awareness (14 studies), affect (11 studies), and cause ( 8 studies). The frequent application of impact and likelihood is not startling given that flood risk is usually defined by the product of the probability that a flood hazard (likelihood) occurs with its consequences (impact). Most studies thus focus on both aspects in their measurement of flood-risk perception.

\subsection{Examining behavior}

People can adapt to floods by taking various adaptive measures, such as raising one's home above the highest flood level, by placing sand bags, or by taking out flood insurance. Lindell and Perry ${ }^{(70)}$ suggested classifying adaptive measures according to the phases of the hazard life cycle: (1) mitigation, (2) preparedness, and (3) recovery. The three phases each occur at a different time relative to the actual flood event, or more generally, at different times during the consecutive hazard phases, also known as the hazard life cycle or safety chain. ${ }^{(71,72)}$ Thus, the adaptive measures that people take when a flood threat is absent can be regarded as mitigation measures. Because these adaptive measures do not require action during impact, Lindell and Perry ${ }^{(70)}$ classified them as "passive protection measures" (e.g., raisings one's home above the highest known flood level). Preparedness

\footnotetext{
${ }^{1}$ In the case of theoretically supported research, the original items for risk perception are displayed in the table.
} 
measures, conversely, are last-call safety measures that are implemented shortly before or during impact ("active protection measures," such as placing sand bags, moving furniture to upper floors, evacuation, and so on). Recovery measures support people in returning to a normal state and in recovering their equilibrium. Flood insurance is such a recovery measure, because it helps people to deal with the financial consequences of floods.

In Table I, a primary distinction is made between mitigation and preparedness measures (next to "BV" = Behavioral variables). Specific attention is further given to studies that focus on insurance, information seeking, and evacuation. Not surprisingly, the broader classes of mitigation behavior (26 studies) and preparedness behavior (18 studies) are more often reported on than the more-specific behaviors, such as flood insurance (14 studies), information seeking ( 7 studies), evacuation (4 studies), and non-protective responses (4 studies). A further classification analysis is imperative but will not be made here. Instead, we will shift our focus to the theories and variables that have been applied to predict people's behavior in general. Distinction is made between the so-called Expectancy Valence theories (e.g., Protection Motivation Theory), applications of the contingent valuation method, and qualitative approaches. The section ends with a brief overview of studies that have examined the above-mentioned behaviors but that have not employed a formal theory.

\subsubsection{Expectancy Valence approaches}

In the field of environmental hazards, researchers have tried to explain people's adaptive behaviors most often by applying Expectancy Valence (EV) models. EV models are rooted in Vroom's ${ }^{(73)}$ expectancy theory, which proposes that people's behavior can be predicted from their valences for different outcomes (e.g., desire to protect oneself against a perceived flood risk), the instrumentalities of their performance of actions leading to those outcomes (e.g., installing flood barriers), and expectancies about the relationship between their effort and successful performance (e.g., expected flood-risk reduction). Various more specific theoretical models dealing with how people adapt to environmental hazards have adopted the propositions of EV theory. In our flood-risk database these 
theories include the Protection Motivation Theory (PMT), the Protective Action Decision Model $(\mathrm{PADM}),{ }^{(38,70)}$ the Motivation Intention Volition Model (MIV) ${ }^{(58)}$ and the Risk Information Seeking and Processing model (RISP). ${ }^{(74)}$

Both Grothmann and Reusswig ${ }^{(75)}$ and Zaalberg et al. ${ }^{(50)}$ have applied the Protection Motivation Theory to flood risks. Central to PMT are two processes: threat appraisal and coping appraisal. While threat appraisal refers to one's risk perception, coping appraisal expresses a person's perceived ability to cope with and avert being harmed by a threat in an effective way. More specifically, PMT defines three constructs that predict coping appraisals, namely response efficacy (the extent to which something is perceived as effective for reducing a threat), self-efficacy (the level of confidence in one's ability to undertake the recommended preventive behavior), and response costs (assumed cost of taking the preventive behavior). The theory further considers the influence of non-protective responses, such as denial, fatalism, and wishful thinking. Grothmann and Reusswig ${ }^{(75)}$ found that both threat and coping appraisal determined people's adoption of flood-hazard adjustments in the past (e.g., construction of structural measures, purchase of protection devices, and the like). Zaalberg et al. ${ }^{(50)}$ took these results one step further by looking at the individual contributions of perceived vulnerability, severity, and response- and self-efficacy. While they found significant effects of response-efficacy on behavioral intentions, their measure of self-efficacy did not predict behavioral intentions. This is remarkable because reviews of PMT in other domains (primarily health) have indicated that self-efficacy is one of the strongest predictors of people's intentions and adaptive behavior. ${ }^{(76)}$ A possible explanation lies in the difficult operationalization of self-efficacy, which has been previously reported by Weinstein. ${ }^{(77)} \mathrm{He}$ observed that in PMT-studies measures of self-efficacy often question "the problems individuals expect to encounter in adopting the precaution or doubts about their ability to change current patterns of behavior," which refer more to the barriers or costs to do something (response costs) than to one's self-efficacy.

The Protective Action Decision Model (PADM) ${ }^{(38,70)}$ is closely related to PMT and has especially been applied to earthquake hazards. PADM has extended the concept of response-efficacy to three socalled efficacy attributes (perceived efficacy of hazard adjustments to protect people, to protect 
property, and their utility for other situations). In addition, the efficacy attributes are distinguished from resource requirements (i.e., the extent to which adjustments are perceived to require money, time and effort, knowledge and skills, cooperation from other people, and specialized tools and equipment). Efficacy attributes are thus closely related to PMT's response efficacy, whereas the resource requirements are closely related to PMT's response costs. Studies conducted by Horney et al. ${ }^{(53)}$ and Lindell and Hwang ${ }^{(34)}$ were both inspired by the predictions of PADM but focused on perceived and actual flood risk rather than on the role of the efficacy attributes and resource requirements.

The Motivation-Intention-Volition model (MIV) ${ }^{(58)}$ also relies on individual appraisals and proposes three phases that lead to adaptive behavior. Motivation results from perceived risk but may be hampered by a lack of perceived personal responsibility and tendencies to avoid or suppress the perceived threat. A person's intention to adopt hazard adjustments is further influenced by perceived response and self-efficacy. Finally, in the volition phase intentions are turned into actions depending on the situational barriers that are encountered. Martens et al. ${ }^{(58)}$ employed latent class analysis to differentiate groups according to their motivation. Although their method appeared useful to provide information for targeting risk communications to specific groups, it had limited power to infer the constructs' contributions to the explained variance in people's adjustment decisions.

The Risk Information Seeking and Processing (RISP) framework, developed by Griffin et al., ${ }^{(74)}$ can be distinguished clearly from the previous theories since it deals specifically with information seeking and information processing tendencies (heuristic and systematic processing). The central concept of the model is a construct called "information insufficiency," which is defined as the gap between a person's current knowledge and his/her knowledge threshold (i.e., whether his or her current knowledge is perceived as less than sufficient). Translated to the context of flood risks, Griffin et al. ${ }^{(78)}$ demonstrated that the desire for risk-related information and intentions for information seeking and processing were associated with anger at managing agencies, as well as with greater risk judgment of harm due to future flooding, greater sense of self-efficacy, lower institutional trust, and causal attributions for flood losses as being due to poor government management. Grothmann and 
Reusswig $^{(75)}$ also examined information seeking behavior in relation to coping appraisal, though they could not find a correlation between both constructs.

\subsubsection{Applications of Contingent Valuation Methods}

Rather than a formal psychological theory, CVM is an economical approach to elicit people's preferences for public goods, such as environmental quality or, in this case, flood protection. Specifically, CVM uses survey methods to analyze and explain people's willingness to pay (WTP), which is a monetary assessment of people's preferences.

Zhai pioneered in this study field by applying CVM to people's WTP for flood-risk reduction and for avoiding evacuation inconveniences. A first study—by Zhai et al. ${ }^{(79)}$ — showed that people's WTP for flood-risk measures may increase with per capita income, individual preparedness, and/or experience with flooding, but may decrease with distance from a river, acceptability of flood risk, and provision of environmental information. A second study—by Zhai and Ikeda ${ }^{(80)}$ - examined the relation between flood risk acceptability and the economic value of evacuation (measured by willingness to pay for avoiding evacuation inconvenience). Zhai and Ikeda ${ }^{(80)}$ found that both flood-risk acceptability and homeownership were two major statistically significantly determinants of the WTP. The authors suggested that there is a trade-off in the public WTP's for ex ante versus ex post measures. Later work by Zhai and Ikeda ${ }^{(60)}$ analyzed flood risk acceptability inspired by the Rational Action Paradigm. In particular, the authors argued that the acceptance of risks should be viewed within a multi-risk context. As such, they found that flood-risk perception and acceptability is correlated with the perception of other risks (e.g., technological risks). Finally, Hung ${ }^{(42)}$ incorporated fuzzy-set theory into contingent-valuation analysis to examine people's attitudes toward flood-insurance purchasing under preference uncertainty. Hung found that the perceived level of flood risk, experience with floods, disposable income, as well as house conditions and trust in the government, are influential factors in the decision-making process for insurance purchase. 


\subsubsection{Qualitative approaches}

Whereas standard communication models such as the normative theory (cf. paragraph 2.2) focus on communication in two directions, some authors have suggested qualitative approaches that focus entirely on the receiver of the risk information and his or her risk knowledge, preferences (cf. nonprotective responses), and information seeking behavior.

A promising qualitative method is the mental-models approach, which is widely applied in cognitive psychology. ${ }^{(81)}$ In short, a mental model reflects a person's thought process about his/her observations in the real world. These thought processes are most often identified through qualitative face-to-face interviews. The mental-models approach enables identification of the public's knowledge schemes that are related to the risk, so that the content of the risk communication can be tailored to this knowledge. ${ }^{(82)}$ Assessing what the intended audience already knows or believes about a particular issue is important in designing effective risk-communication messages. ${ }^{(11)}$ The mental-models approach has been employed in Lave and Lave ${ }^{(83)}$ and in Wagner ${ }^{(.32)}$ Both studies showed that mental models are useful instruments for obtaining qualitative information about flood-risk perceptions improving risk communication. Among a number of other conclusions, Lave and Lave ${ }^{(83)}$ mainly found that people know little about flood mitigation and preparedness. They acknowledged the importance of informing individuals about what they could do to make their houses flood proof. Wagner ${ }^{(32)}$ found that local conditions have a major effect on people's knowledge. Those who use many different sources to inform themselves, express fear about natural hazards, or have previous experience with hazards, generally have a better knowledge about the particular hazard.

The usefulness of qualitative research is also demonstrated by Harries, ${ }^{(55)}$ who applied the Social Representations Theory to explain why some individuals are more willing than others to take selfprotective actions against flood risks. The approach revealed that people who are at risk will be more susceptible to risk mitigation if they are able to relinquish their feeling of security, which is determined by representations of home, nature, and society. 


\subsubsection{Non-theoretical findings on adaptive behavior}

A number of studies have examined people's behavior toward flood risks without the use of a formal theory.

Using a probit regression analysis, Botzen et al., ${ }^{(51)}$ for example, found that higher perceived flood probability increased citizens' intentions of purchasing sand bags. Miceli et al. ${ }^{(67)}$ obtained similar results by employing correlational and regression analyses. In contrast to these findings, Brilly and Polic ${ }^{(13)}$ reported that flood concern was not significantly correlated with the preparedness to conduct preventive measures. Instead, they found that place of residence had a strong influence on preparedness intentions. Other researchers have measured and utilized adjustment behavior mainly to pose policy recommendations. Kreibich et al., ${ }^{(27)}$ for example, measured people's mitigation behavior in the context of groundwater flooding in Germany. Based on the very low number of precautionary measures taken by the respondents, they suggested intensifying communication about this specific type of flooding. McEwen, ${ }^{(84)}$ from his side, pled for the implementation of adjustments to ensure that sustainable development of caravan parks is possible. Wong ${ }^{(54)}$ described functional adjustment approaches in rural China to combat flood hazards. Although people reportedly become accustomed to frequent floods, Wong revealed a public demand for financial reserves by the government so that they can invest in hazard-resistant houses.

Regarding evacuation intentions, Horney et al. ${ }^{(53)}$ found that residents with a medium or high floodrisk perception more often evacuated if they lived in an apartment or mobile home rather than a stickbuilt home. This pattern could not be observed for respondents with low-risk perceptions. Other researchers, such as Krasovskaia ${ }^{(52)}$ and Ologunorisa and Adeyemo, ${ }^{(85)}$ measured evacuation intentions but did not test correlations with other variables.

A number of studies have examined people's attitude and intentions relating to purchasing insurance. While in some countries (e.g., Belgium), flood insurance is mandatory (for example, as part of a fireinsurance policy), other countries leave it to the residents' judgment whether to purchase flood insurance. However, it might be difficult for people to make an informed decision toward a lowprobability, high-loss event. ${ }^{(42)}$ Factors that have been related to flood-insurance adoption are 
homeownership, ${ }^{(86)}$ income ${ }^{(84)}$ and flood exposure. ${ }^{(7)}$ Thieken et al. ${ }^{(87)}$ found that insured people, compared with the uninsured, exhibit a higher likelihood of taking precautionary measures, such as collecting information, participating in networks, and adapting building-use and interior equipment. In the aftermath of a large flood event, insured people showed slightly propensity for investing in further mitigation in the future. Thieken et al. ${ }^{(87)}$ caution about this alarming behavior since about one-third of the interviewed households who were affected by the flood neither purchased insurance nor invested in loss mitigation. Finally, several researchers examined attitudes toward insurance descriptively without specific significance tests or analyses on correlations. ${ }^{\text {(e.g. } 31,88,89)}$

Noteworthy are two studies that examined people's risk-seeking behavior in relation to flood risk perception. Benight et al. ${ }^{(41)}$ linked the risk behavior of motorists driving through an intersection with 6 inches of moving water to the experience of flood-related traumas. Botzen et al. ${ }^{(6)}$ applied a riskseeking index on financial risks to the willingness of people to purchase flood insurance.

\subsection{Examining risk communication}

Among our selection of studies, only two have explicitly focused on flood-risk communication. The first study is Griffin and colleagues' ${ }^{(78)}$ attempt to describe the public's risk-communication activity in the context of flood hazards, using the Risk Information Seeking and Processing (RISP) framework (a detailed discussion on their findings was provided in paragraph 6.2.1). A second study examined the impact of flood-risk communication on the perceptions and attitudes of the public. By means of a quasi-experimental study, Terpstra et al. ${ }^{(37)}$ evaluated the effects of a small-scale flood-riskcommunication program in the Netherlands consisting of workshops and focus groups. Two mechanisms of attitude change—direct personal experience and attitude polarization—were measured among the participants of the workshop and the focus group and were subsequently evaluated in a pre-test/post-test control group. In contrast to what was expected, risk communication had only weak effects on the participants' risk perception. In search for an explanation of these findings, the authors addressed a number of issues that should be considered in further research, such as refined scales, 
homogeneous participant samples, and a closer correspondence between information conditions and risk-perception measures. ${ }^{(37)}$

While very few authors have explicitly addressed flood-risk communication in their research, many studies have made recommendations toward risk communication, such as preferred flood probability formats, perceived uncertainty, and information preferences. Keller et al., ${ }^{(36)}$ for example, examined the effect of the flood-probability format on risk perception and found that participants who received risk information concerning a longer time period (e.g., 30 years) perceived more danger compared with participants who received risk information for one year. Bell and Tobin ${ }^{(90)}$ went further into this matter and measured the effects of four descriptive flood uncertainties in a flood-prone community: a 100-year flood, a flood with a 1 percent chance of occurring in any year, a flood with a 26 percent chance of occurring in 30 years, and a flood-risk map. They found that the 1 percent description was more effective in conveying uncertainty than the 100-year description, but less effective in motivating attitudes of concern or protection. Finally, Kreibich et al. ${ }^{(27)}$ measured the respondents' preferences for types of information-dissemination channels regarding groundwater flooding. According to their findings, means of information ideally should be radio, television, newspapers, and the Internet.

\subsection{Other important variables}

A number of variables that have been reported are not incorporated in any theory, or at least have not been tested as such. Among these are empirical results related to (1) knowledge, trust, and protection responsibility, (2) physical exposure and hazard experience, and (3) socio-demographics.

\subsubsection{Knowledge, trust, and protection responsibility}

Hazard knowledge refers to someone's knowledge about a hazard's genesis, its mechanisms of exposure, and types of hazard adjustments that can avoid its impacts. ${ }^{(70)}$ While hazard knowledge is inextricably bound up with approaches such as the RISP model ${ }^{(74)}$ and the mental-models 
$\operatorname{approach}^{(32,83)}$ (cf. paragraph 6.2), it has been found a difficult construct to quantify. ${ }^{\left({ }^{(c .78)}\right.}$ Most studies therefore operationalize hazard knowledge as perceived knowledge, by asking respondents to what extent they think or believe their knowledge reaches about risk-related topics. As such, perceivedhazard knowledge is generally found strongly linked to perceived vulnerability or feeling of security. ${ }^{(91)}$ Botzen et al. ${ }^{(6)}$ quantified hazard knowledge by asking respondents about the causes of a flood. They found that individuals with little knowledge of the causes of floods have lower perceptions of flood risk. This outcome is supported by Raaijmakers et al., ${ }^{(49)}$ who state that provision of flood-risk information to the public usually increases their awareness or perception. Ruin et al. ${ }^{(92)}$ operationalized knowledge in yet another way, i.e., by employing cognitive mapping to understand people's decisions regarding flood risks.

When people lack knowledge about a hazard, their risk judgments are based on the degree to which they trust the responsible risk managers. As such, knowledge is conceptually related to trust. The construct of trust has been studied in the context of the Psychometric Paradigm, ${ }^{(45)}$ affect heuristics, ${ }^{(69)}$ PMT, ${ }^{(75)}$ and RISP. ${ }^{(74)}$ Trust may refer to institutional trust (e.g., in the government's abilities to cope with a flood hazard) or trust in specific flood-protection measures (e.g., the resistance of a sea wall). Terpstra $^{(69)}$ noted that trust and affect share similarities, since both constructs reduce the complexity of risk judging and consequently serve as a "quick" guide for assessing risks. Both Terpstra ${ }^{(69)}$ and Hung $^{(42)}$ found that trust in public flood protection was negatively related to preparedness and an intention to purchase insurance, respectively, and Grothmann and Reuswig ${ }^{(75)}$ reported that relying on flood protection was negatively correlated with the adoption of flood-mitigation measures in the past as well as information seeking. In contrast, reports by Lin et al. ${ }^{(31)}$ indicated that higher levels of trust or confidence in crisis management and provision of flood warnings (by government, risk experts, and media) increased mitigation intentions, insurance purchase intentions, and information-seeking intentions. These contradicting findings seem hard to explain. It should be noted, however, that the three former studies ${ }^{(42,69,75)}$ focused on the extent to which people trust in public-flood protection (i.e., flood defenses), whereas the latter study ${ }^{(31)}$ focused on the provision of flood warnings in a crisis situation. 
Perceived protection responsibility reflects the degree to which a person feels personally responsible for taking individual protection measures against a hazard. This construct has been addressed mostly in the domain of earthquake hazard. ${ }^{(38)}$ Empirical evidence has shown that adaptive behavior is more likely when people perceive protection as their personal responsibility. In the context of flood risks, most studies confirmed this relationship. For instance, Lara et al. ${ }^{(43)}$ found that personal responsibility is positively correlated with mitigating actions such as moving furniture to upper floors and information seeking. However, reports by Terpstra and Gutteling ${ }^{(5)}$ suggest that the correlations of protection responsibility may differ among protective actions. Although a lower damage responsibility was correlated with less-favorable attitudes toward private damage-mitigation actions, the correlation with disaster preparedness attitude was not significant. Moreover, correlations of protection responsibility with behavioral intentions were insignificant for taking both damage mitigation actions and emergency preparedness actions.

\subsubsection{Physical exposure and previous experiences}

To date, effects of physical exposure to flood hazards and experiences with previous flood events have been hardly theorized. Nevertheless, numerous studies have shown that both variables can have effects on risk perception and efficacy beliefs or hazard adjustments.

The physical exposure to a flood hazard is mostly determined by the resident's location, which is related to the visibility of, and the distance or proximity to, the hazard source (e.g., a river, the sea, etc.). Positive correlations between flood hazard proximity and risk perception have been found by Heitz et al. ${ }^{(29)}$ and Lindell and Hwang. ${ }^{(34)}$ From their findings, it seems that people who reside farther away from flood hazard sources (such as coastlines, rivers, and the like) exhibit lower levels of perceived risk. Lindell and Hwang ${ }^{(34)}$ tested whether this outcome is caused by a lack of hazard experience, but they could find only partial rather than complete effects. Some authors reported that proximity of one's home to a river or coastline increases behavioral intentions of taking mitigation and preparedness measures. Botzen et al., ${ }^{(51)}$ for example, reported a marginally significant effect of 
proximity on willingness to buy sand bags. Others have employed hazard proximity and risk perception to predict other variables. Zhang et al., ${ }^{(93)}$ for example, found that flood-risk perception is a significant mediating factor between hazard proximity and property value.

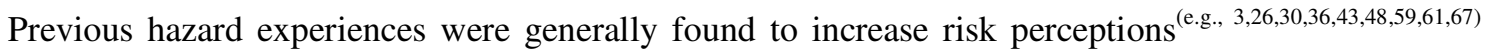
and the likelihood that people adopt hazard adjustments. ${ }^{(\text {e.g. }}{ }^{42,68,75,87)}$ Pagneux et al. ${ }^{(94)}$ found that people with flood experience had more knowledge and better understanding of historical floods. Results by Zhai and Ikeda ${ }^{(80)}$ indicated that evacuations can cause inconveniences, such as shortages of information and food. Such inconveniences were regarded as an important factor for causing low rates of evacuation in Japan. Several authors ${ }^{(\text {e.g. } 70,95)}$ suggested that the effect of experience depends on how people interpret their experiences or what they have learned from them. Factors that shape risk perceptions are the magnitude of the effect, the risk target, and the frequency and recency of experiences. While it is reasonable to assume that large-scale flood hazards will have a greater impact than a local flood, ${ }^{(96)}$ the concept of risk target might need a word of explanation. The risk target indicates whether the respondent is personally affected by the hazard (personal experience) or not (community or vicarious experience). ${ }^{(97)}$ Botzen et al., ${ }^{(6)}$ for example, reported that citizens with previous flood and evacuation experience expressed higher perceived flood likelihood but lower perceived flood consequences, presumably because hardly any of the respondents with flood experience had actually suffered personal flood damage. Finally, Siegrist and Gutscher ${ }^{(3)}$ have shown that more recent and frequent floods lead to higher levels of risk perception depending on the magnitude and the [personal] damage that occurred. Burn ${ }^{(98)}$ summarizes the effect of experience by stating that "prior experience with flood events appear to be most useful when it is recent and relevant to the current event."

Several studies have suggested that the effects of experience on perceived risk and behavior are indirect rather than direct, and are thus mediated by other variables. Lindell and Hwang ${ }^{(34)}$ found that perceived personal flood risk completely mediated the effect of hazard experience on flood-mitigation behavior (e.g., raising electrical components above flood level), but risk perception only partly mediated the effect of experience on flood-insurance purchase. It was suggested that the partial- 
mediation effect was found because other unmeasured variables may also mediate effects of experience. Extensive mediation analyses by Zaalberg et al. ${ }^{(50)}$ indicated that Dutch flood victims as compared with non-victims had stronger coping intentions because they perceived themselves as more vulnerable to future floods, which in turn resulted from experiencing stronger negative emotions (e.g., fear) caused by their previous flood experiences. Interviews in Switzerland also pointed to the idea that fear of future flood damage is a more important determinant of precautionary behavior for victims than for non-victims. ${ }^{(68)}$ Their analyses indicated that victims compared with non-victims expressed stronger negative (e.g., fear) and positive (e.g., sociability) emotions as a result of their flood experiences, received more social support from family and friends, worried more about future flooding, perceived themselves as more vulnerable, and perceived the consequences of future flooding as more severe. Flood victims also perceived higher response efficacy and had stronger intentions to take adaptive actions (e.g., moving furniture upstairs) than non-victims, but they did not differ from non-victims in their perceived response efficacy of preventive actions (e.g., putting sand bags in front

of the house) and their intentions to take these actions. Terpstra ${ }^{(69)}$ reported that emotions evolving from previous flood-hazard experiences failed to have significant, direct effects on flood preparedness intentions among Dutch citizens. Mediation analyses indicated that although emotions influenced preparedness intentions indirectly, the mediation paths differed among sample locations. The author argued that the discrepancy might be explained by the severity of the disaster consequences combined with the time at which the emotions were assessed. In particular, Terpstra ${ }^{(69)}$ investigated emotions two months after a heavy storm, about fifteen years after mild river floods, and fifty-five years after a severe flood disaster. Because these emotions become less salient as time goes by, the impact of these emotions on risk perceptions and adaptive behaviors fades away too.

\subsubsection{Socio-demographics}

Socio-demographic characteristics are examined in almost every study on flood-risk perception. While most studies measure these characteristics primarily to describe the sample and demonstrate its representativeness, ${ }^{(59)}$ significant—but often small—correlations are regularly found with risk 
perception. ${ }^{(99)}$ The most important characteristics seem to be age, gender, education, income, and home ownership. Age is generally found to be positively correlated with flood risk perception, ${ }^{(34,48)}$ although negative outcomes have also been found. ${ }^{(6)}$ As for gender, several studies ${ }^{(\text {e.g. } 30,34)}$ found that men have, on average, lower perceived levels of flood risks than women. However, Botzen ${ }^{(6)}$ discovered the opposite relation. Regarding education, less-educated people usually show higher levels of risk perception. ${ }^{(40)}$ Ho et al. ${ }^{(30)}$ refine this relation by considering the controllability of the flood risk. They suggest that people with more years of education may obtain and understand new information more easily. As a result, they may be aware of more mitigation actions from local governments and experts and thus may feel a higher degree of controllability over a disaster. Often related to the educational level is income, since people with a superior educational level have, on average, larger incomes. ${ }^{(40)}$ Lopez-Marerro and Yarnal $^{(44)}$ also recognize a positive correlation between income and housing conditions (construction materials) and housing location, as people with lower incomes will predominantly reside in poorer housing conditions in less favorable areas (e.g., flood-prone areas). In general, income is negatively correlated to risk perception, ${ }^{(34,93)}$ though statistical significance is often absent. ${ }^{(6,30)}$ Finally, home ownership has also been related to perceived risks. Several studies ${ }^{(\text {e.g. } 27,61)}$ suggests that owning a property results in higher levels of perceived risk than renting a residence. Grothmann and Reusswig ${ }^{(75)}$ explain that home owners may suffer much more loss than tenants since significant flood damage occurs to the building itself.

\section{DISCUSSION}

This paper presented an overview of the state of the art in the research on perception and communication of flood risks, including 57 studies from 22 different countries. Two aspects stand out in this review. First is the diversity of approaches including the use of theories, measurement instruments, and data-analytic procedures. The study field is still very young and subsequently attracts many researchers from different study domains. Researchers bring different approaches, constructs, and methods to their analyses, which explains why similar goals are assessed in different 
ways ${ }^{\left({ }^{(c .10)}\right.}$ Second, there is almost a complete absence of true risk-communication research. In this final section we discuss these issues and propose a research agenda for the near future.

\subsection{Theoretical and methodological issues}

Many theories were used to predict people's risk perceptions (Psychometric Paradigm, heuristics) and their adaptive behaviors (e.g., PMT, PADM, CVM). Qualitative approaches were also used to map out people's mental models of flood risks. Application of well-established theoretical frameworks seems necessary to propose sound (i.e., theoretically justified) hypotheses that can be tested empirically using smart research designs, validated measurement instruments, and sophisticated data analyses. Ultimately, this will lead to theoretical progression and result in a more complete understanding of people's flood-risk perception and their (non-)adaptive behaviors. So far, however, the majority of studies (i.e., 60 percent) refrained from using theories. As a result, approaches and methods within the field are often very heterogeneous, which makes results from different studies difficult to compare. This might be one of the main reasons why some findings don't seem to confirm each other or even appear to be inconsistent with each other. For example, many studies presented their own regression models for the prediction of risk perceptions, attitudes (e.g., toward government relief), or intentions (e.g., buying flood insurance). Although significant predictors were mostly found in these models, explained variances were often relatively low, indicating noise or the presence of other, non-measured confounding variables.

While it is impossible to cancel out noise, it is a challenge to improve measurement instruments. We suggest three steps to tackle this issue. First, authors can improve their measurement instruments by carefully considering the theoretical constructs that are needed to measure/predict flood risk perceptions and adaptive behaviors. Second, the operationalization of theoretical constructs can be ameliorated by copying or at least by reflecting on previously reported questionnaire items. Third, authors should report on the reliability of their measures, as well as their means, standard deviations, 
and correlations. In particular, structural-equation modeling (SEM) can be used to explicitly identify the presence of noise (unreliability) in measurement instruments.

Another point that needs more attention is the analysis of mediation and causality. For instance, three studies tested the extent to which the effects of flood experience on adaptive behavior were mediated by flood-risk perceptions. ${ }^{(34,50,69)}$ In other words, flood experiences were expected to stimulate adaptive behavior because experiences influence people's risk perceptions and their perceptions of flood-hazard adjustments, which in turn influence their adaptive behaviors. Performing mediation analyses is important for understanding the relations between variables, which is indispensible for advancing theories. In addition, the word "because" suggests that one was able to establish causality-for instance, that perceived risk causes adaptive behavior and not the other way around. ${ }^{\text {(cf.100) }}$ This is important since many studies have assumed causal relations to predict risk perceptions and/or behavior, but provided evidence based on cross-sectional research designs. Although it is tempting to report on causality, cross-sectional surveys cannot provide sufficient evidence to do so. ${ }^{(34)}$ To test causal relations, [quasi] experimental and longitudinal research designs are needed in addition to the cross-sectional surveys. ${ }^{(38)}$ Although it has been argued that it is difficult to simulate flood experiences with severe financial losses in experiments, ${ }^{(68)}$ effects of direct (personal) flood experiences and indirect (vicarious) experiences produced by social communications can be measured in longitudinal surveys. ${ }^{(69)}$

\subsection{Communication issues}

It is now widely acknowledged that risk communication can strengthen people's risk awareness and motivate those at risk to take preventive actions and be prepared for an emergency case. ${ }^{(101)}$ It is further accepted that the knowledge of the public's risk perception is an important factor in building effective risk-communication strategies. ${ }^{(21)}$ However, it is apparent that only a few studies take the plunge to define practical recommendations, particularly for flood-risk communication. Moreover, most of these recommendations are indefinite, and the focus or objective of the risk message often 
differs from situation to situation. Knocke and Kolivras, ${ }^{(59)}$ for example, emphasized the need to elaborate educational programs on flash-flood risks. These programs could be accomplished through training sessions, presentations at public functions, informational fliers, and so on, that focus on understanding flood causes and possible consequences, increasing awareness of warning sources, and informing the public about available tools and data. Instead of raising awareness and understanding, Kreibich et al. ${ }^{(27)}$ stated that communication should primarily concentrate on the necessity of individual preparedness. Bell and Tobin ${ }^{(90)}$ suggested that more extensive use of qualitative methods would also help in the practical interpretation of statistical relationships. Finally, Martens et al..$^{(58)}$ urged more attention to the heterogeneity of the public. It is not sufficient to simply provide the same message to all individuals at risk because they will perceive this information differently and will subsequently respond in different ways. Although all these recommendations undoubtedly have important value in communicating flood risks, their overall goal remains vague.

We believe two reasons are at the basis of this vagueness. First, empirical research on the direct effects of flood-risk communication is very limited to date. The study of Terpstra et al., ${ }^{(37)}$ which reported on the impact of a small-scale flood risk communication program in a quasi-experimental setting, has cleared the way for more research in this context. Second, there is very limited theoretical background with regard to flood-risk communication. Griffin et al. ${ }^{(78)}$ applied their RISP model in the context of flood hazards, but many questions remain regarding the cognitive and affective processes that play a role in people's information-seeking behavior.

In order to reduce the vagueness and define clear strategies in flood-risk communication, more research into the theoretical concepts of risk communication and its direct effects on people's behavior is urgently required.

\subsection{Future research agenda}

This review article has shown that the study field has undergone remarkable growth during recent years. Studies from around the world have been conducted, and empirical evidence is being gathered 
at an increasing pace. Nevertheless, as the previous section indicated, there is room for additional research in the field.

First of all, future research should strive for more theoretical support and more methodological "openness." There exists a wide range of theories that may fulfill the needs of a similarly wide range of objectives. Whether the focus is on a strict analysis of people's risk perception, whether it is the intention to assess people's attitudes toward preparedness measures, or whether it is the aim to affect people's behavior, it is always possible to rely on existing theories, models, or frameworks. Profound empirical testing of previous theories may lead to new insights and model improvementsassuming that the selection and measurement of constructs is "open" and well-grounded. After all, it can be problematic if studies do not report the contents of the items employed, since it precludes other scholars from verifying how constructs were measured or results were obtained.

With regard to theoretical extensions and variations, future research could work toward a framework that puts more emphasis on the effects of physical exposure and hazard experience. Although both constructs have been examined quite often, they have hardly been theorized. ${ }^{(34,61,93)}$ Future studies in risk perception could further attempt to employ experimental and longitudinal designs more often, in order to enable causality inference.

It has been shown that research on the determinants and the effects of flood-risk communication is in its early stages. Future research should address the relation between flood-risk perception and floodrisk communication more thoroughly. It is apparent that many perception studies refer to risk communication in their "further research," ${ }^{(3,33,93)}$ but very few link both. ${ }^{(27,90)}$ More research should be conducted on people's information preferences, ${ }^{(34)}$ on the effects of risk information on people's behavior, ${ }^{(37)}$ and on fostering private adaptation. ${ }^{(75)}$. Stemming from the latter, future research should also look at various cost-effective mitigation measures and how these can be implemented in traditional flood-risk management. ${ }^{(51)}$

In sum, there is still considerable work to do. Inspired by Botzen, ${ }^{(6)}$ we can say that research on floodrisk perception and communication is still in its infancy. Although both research domains have come 
a long way in the past decades, there is need for more definition, clearer methods, and more comparability.

\section{APPENDIX}

The table below presents the selection of articles reviewed in this paper. 
Table I Overview of peer-reviewed empirical studies in flood risk perception research

\begin{tabular}{|c|c|c|c|}
\hline $\begin{array}{l}\text { Author(s), } \\
\text { Year }\end{array}$ & $\begin{array}{l}\text { Research design } \\
\text { [Country, Flood type } \\
\text { Respondents, Survey delivery method, } \\
\text { Theory] }\end{array}$ & $\begin{array}{l}\text { Research variables } \\
\text { [Risk perception (RP) } \\
\text { Behavioral variables (BV) } \\
\text { Other important variables (OIV)] }\end{array}$ & Key findings \\
\hline Ali, 2007(39) & $\begin{array}{l}\text { Bangladesh, River } \\
453 \text { flood-affected families, FI } \\
\text { No specific theory }\end{array}$ & $\begin{array}{l}\text { RP: Cause } \\
\text { BV: Mitigation, Preparedness } \\
\text { OIV: Experience, Risk area, Demographics }\end{array}$ & $\begin{array}{l}\text { Victims of the Bangladesh } 1994 \text { flood view the event as a natural hazard. Policy recommendations are } \\
\text { given to improve flood protection, management programs, and to raise self-dependency in the flood } \\
\text { area. }\end{array}$ \\
\hline $\begin{array}{l}\text { Armas \& } \\
\text { Avram, } \\
2009(40)\end{array}$ & $\begin{array}{l}\text { Romania (Danube Delta), River } \\
153 \text { residents in } 3 \text { regions, FI } \\
\text { No specific theory }\end{array}$ & $\begin{array}{l}\text { RP: Affect, Impact } \\
\text { BV: Mitigation } \\
\text { OIV: Locus of control }\end{array}$ & $\begin{array}{l}\text { Internal and external control factors are found essential in establishing a person's psychosocial } \\
\text { vulnerability. Lack of resources (external control) and mistrust in the support given (internal control) } \\
\text { emphasize non-adaptive behaviours. }\end{array}$ \\
\hline $\begin{array}{l}\text { Arthur et al, } \\
2009(28)\end{array}$ & $\begin{array}{l}\text { UK (Edinburgh), Sewage }(+) \\
173 \text { residents, FI } \\
\text { No specific theory }\end{array}$ & $\begin{array}{l}\text { RP: Impact, Cause } \\
\text { OIV: Experience, Demographics }\end{array}$ & $\begin{array}{l}\text { People perceive the most severe sewage failures as those that result in the flooding of domestic } \\
\text { properties. Public-amenity areas are viewed as being significantly less important. A failure-consequence } \\
\text { model is constructed. }\end{array}$ \\
\hline $\begin{array}{l}\text { Bell \& Tobin, } \\
\text { 2007(90) }\end{array}$ & $\begin{array}{l}\text { USA (Texas, Wimberly), Flash } \\
45 \text { adults, FI } \\
\text { No specific theory }\end{array}$ & $\begin{array}{l}\text { RP: Affect } \\
\text { OIV: Risk area }\end{array}$ & $\begin{array}{l}\text { Statistical analysis and qualitative observation show a disjuncture between understanding and } \\
\text { persuasion of flood-chance description. There is a preference for concrete references in describing risk. }\end{array}$ \\
\hline $\begin{array}{l}\text { Benight et al., } \\
2007^{(41)}\end{array}$ & $\begin{array}{l}\text { USA (Colorado/Texas), Flash } \\
342 \text { flood-plain residents, MQ } \\
\text { No specific theory }\end{array}$ & $\begin{array}{l}\text { RP: Awareness, Affect, Impact } \\
\text { BV: Risk behavior } \\
\text { OIV: Experience, Risk area }\end{array}$ & $\begin{array}{l}\text { Significant differences are found between questions related to general beliefs about flash floods and } \\
\text { warning perceptions/anticipated actions during a flash flood at home. Results suggest high trauma } \\
\text { exposure may lead to more threat sensitivity and a higher probability of initiated action in a home-based } \\
\text { flash flood. }\end{array}$ \\
\hline $\begin{array}{l}\text { Botzen et al., } \\
2009(6)\end{array}$ & $\begin{array}{l}\text { The Netherlands, River } \\
982 \text { homeowners, } O Q \\
\text { No specific theory }\end{array}$ & $\begin{array}{l}\text { RP: Likelihood, Impact, Cause } \\
\text { BV: Risk behavior } \\
\text { OIV: Experience, Distance from river, Elevation relative to water } \\
\text { level, Demographics }\end{array}$ & $\begin{array}{l}\text { In general, perceptions of flood risk are low. Four factors are found to determine risk perceptions: (1) } \\
\text { actual risk levels, (2) dike protection, (3) knowledge of the flood cause, and (4) age and education. } \\
\text { Recommendations are presented for policy makers. }\end{array}$ \\
\hline $\begin{array}{l}\text { Botzen et al., } \\
2009(51)\end{array}$ & $\begin{array}{l}\text { The Netherlands, River } \\
509 \text { homeowners, } \mathrm{OQ} \\
\text { No specific theory }\end{array}$ & $\begin{array}{l}\text { RP: Likelihood, Impact } \\
\text { BV: Mitigation, Preparedness, Insurance } \\
\text { OIV: Experience, Distance from river, Elevation relative to water } \\
\text { level, Dike protection }\end{array}$ & $\begin{array}{l}\text { Many homeowners are willing to invest in mitigating measures, particularly in water barriers, in } \\
\text { exchange for a premium reduction. A probit model indicates that existing arrangements for } \\
\text { compensating flood damage, risk awareness and perceptions, and geographical characteristics are } \\
\text { important determinants in the decision to undertake mitigation. }\end{array}$ \\
\hline $\begin{array}{l}\text { Brilly \& Polic, } \\
2005^{(13)}\end{array}$ & $\begin{array}{l}\text { Slovenia (Celje), River } \\
157+208 \text { residents, } \mathrm{FI} \\
\text { No specific theory }\end{array}$ & $\begin{array}{l}\text { RP: Awareness, Likelihood, Impact, Affect } \\
\text { BV: Preparedness, Insurance } \\
\text { OIV: Experience, Risk area }\end{array}$ & $\begin{array}{l}\text { The perception of a flood threat depends, to a certain degree, on the place of residence. Solidarity and } \\
\text { the importance of insurance against floods are shown. }\end{array}$ \\
\hline $\begin{array}{l}\text { Burningham et } \\
\text { al., 2008(61) }\end{array}$ & $\begin{array}{l}\text { UK (England/Wales), River } \\
941 \text { residents, FG/FI } \\
\text { No specific theory }\end{array}$ & $\begin{array}{l}\text { RP: Awareness } \\
\text { OIV: Experience, Risk area, Length of time at present address, } \\
\text { Social class, Demographics }\end{array}$ & $\begin{array}{l}\text { The most influential factor in predicting flood risk awareness is social class, followed by flood experience } \\
\text { and length of time in residence. The importance of engaging with local perspectives on risk and making } \\
\text { local people part of 'awareness-raising' processes are underlined. }\end{array}$ \\
\hline $\begin{array}{l}\text { Correia et al., } \\
1998^{(57)}\end{array}$ & $\begin{array}{l}\text { Portugal (Setubal),Flash } \\
39 \text { residents }+42 \text { shopkeepers }+20 \\
\text { experts, FI } \\
\text { No specific theory }\end{array}$ & $\begin{array}{l}\text { RP: Likelihood, Cause } \\
\text { BV: Mitigation, Preparedness } \\
\text { OIV: Experience, Residential history }\end{array}$ & $\begin{array}{l}\text { An extensive interview program is presented with residents and shopkeepers - with and without flood } \\
\text { experience, as well as flood experts and decision makers. Recommendations are given for public } \\
\text { participation and policy issues. }\end{array}$ \\
\hline $\begin{array}{l}\text { De Villiers \& } \\
\text { Maharaj, } \\
\text { 1994(89) }\end{array}$ & $\begin{array}{l}\text { South Africa (Durban), River } \\
60 \text { households, Q(n.s.) } \\
\text { No specific theory }\end{array}$ & $\begin{array}{l}\text { RP: Likelihood, Cause } \\
\text { BV: Mitigation, Insurance } \\
\text { OIV: Experience, Distance from river, Protection responsibility }\end{array}$ & $\begin{array}{l}\text { Nearly } 50 \% \text { of the respondents live in a floodprone area but are nonetheless completely unaware of a } \\
\text { flood threat. A more sophisticated flood-warning system is suggested to alleviate the problem. }\end{array}$ \\
\hline
\end{tabular}




\begin{tabular}{|c|c|c|c|}
\hline $\begin{array}{l}\text { Author(s), } \\
\text { Year }\end{array}$ & $\begin{array}{l}\text { Research design } \\
\text { [Country, Flood type } \\
\text { Respondents, Survey delivery method, } \\
\text { Theory] }\end{array}$ & $\begin{array}{l}\text { Research variables } \\
\text { [Risk perception (RP) } \\
\text { Behavioral variables (BV) } \\
\text { Other important variables (OIV)] }\end{array}$ & Key findings \\
\hline $\begin{array}{l}\text { Figueiredo et } \\
\text { al., } 2009 \text { (7) }\end{array}$ & $\begin{array}{l}\text { Portugal (Agueda), River } \\
823 \text { residents, FI/MQ } \\
\text { No specific theory }\end{array}$ & $\begin{array}{l}\text { RP: Cause } \\
\text { BV: Mitigation, Insurance } \\
\text { OIV: Experience, Risk area, Protection responsibility }\end{array}$ & $\begin{array}{l}\text { The inhabitants of Agueda (Portugal) show a tendency toward acceptance and coping with flood risk. } \\
\text { They recognize the advantages of occupying the floodplains, despite the impossibility of eliminating the } \\
\text { flood risk. }\end{array}$ \\
\hline $\begin{array}{l}\text { Ge et al., } \\
\text { 2010(33) }\end{array}$ & $\begin{array}{l}\text { China (Yangtze Delta), River (+) } \\
275 \text { citizens/policy makers, MQ } \\
\text { Psychometric Paradigm }\end{array}$ & $\begin{array}{l}\text { RP: Voluntariness, Immediacy, Known to exposed / science, } \\
\text { Controllability, Newness, Catastrophic potential, Dread, Severity of } \\
\text { consequences }\end{array}$ & $\begin{array}{l}\text { Risk-perception differences are found between comparative groups (China and USA), which show that } \\
\text { the society and culture influence people's perception of risk. }\end{array}$ \\
\hline $\begin{array}{l}\text { Griffin et al., } \\
2008(78)\end{array}$ & $\begin{array}{l}\text { USA (Milwaukee), River } \\
401 \text { residents, TI } \\
\text { Risk Information Seeking and Processing }\end{array}$ & $\begin{array}{l}\text { RP: Risk judgment } \\
\text { BV: Information seeking } \\
\text { OIV: Experience, Information insufficiency, Institutional trust, } \\
\text { Personal efficacy, Demographics }\end{array}$ & $\begin{array}{l}\text { Anger at managing agencies is associated with the desire for information and active information seeking } \\
\text { and processing, as well as with greater risk judgment of harm from future flooding, greater sense of } \\
\text { personal efficacy, and lower institutional trust. }\end{array}$ \\
\hline $\begin{array}{l}\text { Grothmann \& } \\
\text { Reusswig, } \\
\text { 2006(75) }\end{array}$ & $\begin{array}{l}\text { Germany (Cologne), River } \\
157 \text { residents, TI } \\
\text { Protection Motivation Theory }\end{array}$ & $\begin{array}{l}\text { RP: Perceived probability, Perceived severity, Fear } \\
\text { BV: Mitigation, Preparedness, Information seeking, Non-protective } \\
\text { responses } \\
\text { OIV: Experience, Trust in flood protection }\end{array}$ & $\begin{array}{l}\text { The explanatory power of the PMT model is shown. To motivate people for damage preventing, it } \\
\text { seems essential to communicate not only the risk of flooding and its potential consequences, but also } \\
\text { the possibility, effectiveness and cost of private precautionary measures. }\end{array}$ \\
\hline $\begin{array}{l}\text { Harries, } \\
2008^{(55)}\end{array}$ & $\begin{array}{l}\text { United Kingdom, Flood (n.s.) } \\
40 \text { householders, Fl/FG } \\
\text { Social Representations Theory }\end{array}$ & $\begin{array}{l}\text { BV: Non-protective responses } \\
\text { OIV: Representational barriers (home, society, nature) }\end{array}$ & $\begin{array}{l}\text { The desire to feel secure can sometimes deter people from taking actions that would reduce the actual } \\
\text { physical damage of a hazardous natural event. The role of emotions and social representations in risk } \\
\text { perception is underlined. }\end{array}$ \\
\hline $\begin{array}{l}\text { Heitz et al., } \\
2006^{(29)}\end{array}$ & $\begin{array}{l}\text { France (Alsace), Mud } \\
34 \text { citizens/farmers/councillors, MQ } \\
\text { No specific theory }\end{array}$ & $\begin{array}{l}\text { RP: Awareness, Impact } \\
\text { OIV: Risk area, Institutional trust }\end{array}$ & $\begin{array}{l}\text { Significant differences in risk perception are found among the three types of stakeholders } \\
\text { (ciitzens/farmers/councilors), particularly due to the location of these groups within the catchment. There } \\
\text { is support for information provided by the local authorities. }\end{array}$ \\
\hline $\begin{array}{l}\text { Ho et al., } \\
\text { 2008(30) }\end{array}$ & $\begin{array}{l}\text { Taiwan, Flood (n.s.) (+) } \\
2559 \text { households, TI } \\
\text { Psychometric Paradigm }\end{array}$ & $\begin{array}{l}\text { RP: Likelihood, Affect, Impact, Controllability, Knowledge of private } \\
\text { mitigation actions } \\
\text { OIV: Experience, Demographics }\end{array}$ & $\begin{array}{l}\text { (1) There is general concern about hazards' consequences; (2) negative associations between the } \\
\text { controllability and the perceived impact are high for landslide victims, not for flood victims; and (3) } \\
\text { disaster type, gender, and previously experienced disasters are good predictors of victims' attitudes } \\
\text { toward natural disasters. }\end{array}$ \\
\hline $\begin{array}{l}\text { Horney et al., } \\
\text { 2010(53) }\end{array}$ & $\begin{array}{l}\text { USA (North Carolina), Coastal } \\
570 \text { coastal residents, FI } \\
\text { Protective Action Decision Model }\end{array}$ & $\begin{array}{l}\text { RP: Impact } \\
\text { BV: Evacuation } \\
\text { OIV: Hurricane experience, Type of home, Risk area, Home } \\
\text { location }\end{array}$ & $\begin{array}{l}\text { The intention to evacuate and home type are important confounders of the association between actual } \\
\text { risk and evacuation. However, while coastal residents' perceived risk of flooding is correlated with their } \\
\text { actual flood risk, neither seems associated with evacuation. }\end{array}$ \\
\hline Hung, 2009(42) & $\begin{array}{l}\text { Taiwan (Keelung basin), River } \\
405 \text { homeowners, } \mathrm{FI} \\
\text { Fuzzy Contingent Valuation }\end{array}$ & $\begin{array}{l}\text { RP: Likelihood } \\
\text { BV: Insurance } \\
\text { OIV: Experience, Distance from river, Risk area, Trust, Preference } \\
\text { uncertainty, Demographics }\end{array}$ & $\begin{array}{l}\text { Perceived levels of flood risk, experience with flood, disposable income, as well as house conditions, } \\
\text { are found to be influential factors in the decision-making process for insurance purchase. Uncertainty } \\
\text { and conservatism are the key factors that cause respondents to reject buying insurance. }\end{array}$ \\
\hline $\begin{array}{l}\text { Kellens et al., } \\
2011^{(48)}\end{array}$ & $\begin{array}{l}\text { Belgium, Coastal } \\
619 \text { householders, MQ } \\
\text { No specific theory }\end{array}$ & $\begin{array}{l}\text { RP: Likelihood, Affect, Impact } \\
\text { OIV: Experience, Risk area, Permanent residence, Demographics }\end{array}$ & $\begin{array}{l}\text { By use of multiple regression analysis, the risk perception of coastal residents (both permanent and } \\
\text { temporal) is found to be primarily influenced by actual flood-risk estimates, age, gender, and experience } \\
\text { with previous flood hazards. }\end{array}$ \\
\hline $\begin{array}{l}\text { Keller et al., } \\
2006(36)\end{array}$ & $\begin{array}{l}\text { Switzerland, Flood (n.s.) } \\
\text { Three experiments: } 170+92 \text { students } \\
\text { (FI), } 1598 \text { citizens (MQ) } \\
\text { Affect and Availability Heuristics }\end{array}$ & $\begin{array}{l}\text { RP: Likelihood, Impact } \\
\text { OIV: Experience }\end{array}$ & $\begin{array}{l}\text { Risk perception is influenced by: (1) length of time in risk information, (2) previous flood experience, and } \\
\text { (3) affect (manipulated using photographs with flooded houses). The importance of evoking negative } \\
\text { affect (fear) in risk communication in order to raise risk perception is stressed. }\end{array}$ \\
\hline
\end{tabular}




\begin{tabular}{|c|c|c|c|}
\hline $\begin{array}{l}\text { Author(s), } \\
\text { Year }\end{array}$ & $\begin{array}{l}\text { Research design } \\
\text { [Country, Flood type } \\
\text { Respondents, Survey delivery method, } \\
\text { Theory] }\end{array}$ & $\begin{array}{l}\text { Research variables } \\
\text { [Risk perception (RP) } \\
\text { Behavioral variables (BV) } \\
\text { Other important variables (OIV)] }\end{array}$ & Key findings \\
\hline $\begin{array}{l}\text { Knocke \& } \\
\text { Kolivras, } \\
2007^{(59)}\end{array}$ & $\begin{array}{l}\text { USA (Virginia), Flash } \\
300 \text { residents, } O Q \\
\text { No specific theory }\end{array}$ & $\begin{array}{l}\text { RP: Awareness, Likelihood, Impact } \\
\text { OIV: Experience, Risk area, Length of residency, Verbal } \\
\text { description of flash floods and impacts, Information preferences }\end{array}$ & $\begin{array}{l}\text { A knowledge base of flash floods is demonstrated, but is not advanced enough for proper awareness. } \\
\text { Risk perception is associated with age and exposure. Recommendations are given toward improving } \\
\text { the flash flood warning system. }\end{array}$ \\
\hline $\begin{array}{l}\text { Krasovskaia, } \\
2001^{152)}\end{array}$ & $\begin{array}{l}\text { Norway (Glomma catchment), River } \\
24 \text { experts (FG) }+900 \text { citizens (TI) } \\
\text { No specific theory }\end{array}$ & $\begin{array}{l}\text { RP: Likelihood, Impact } \\
\text { BV: Evacuation } \\
\text { OIV: Experience }\end{array}$ & $\begin{array}{l}\text { Unrealistic flood-hazard perceptions are found among the general public, which are attributed to } \\
\text { insufficient risk communication. Increased transparency is deemed crucial to improving risk knowledge } \\
\text { and participation. }\end{array}$ \\
\hline $\begin{array}{l}\text { Krasovskaia et } \\
\text { al., 2007(26) }\end{array}$ & $\begin{array}{l}\text { Germany, Netherlands, Norway, Sweden } \\
\text { UK, Floods (n.s.) } \\
3996 \text { flood-plain residents, TI } \\
\text { No specific theory }\end{array}$ & $\begin{array}{l}\text { RP: Awareness, Likelihood, Affect } \\
\text { BV: Mitigation } \\
\text { OIV: Experience, Protection responsibility }\end{array}$ & $\begin{array}{l}\text { In general, the international sample shows a limited interest in flood hazards, and a passiveness and } \\
\text { reluctant attitude toward moving. The importance of finding a consensus between public and authorities } \\
\text { regarding risk tolerance is underlined. }\end{array}$ \\
\hline $\begin{array}{l}\text { Kreibich et al., } \\
2007^{(47)}\end{array}$ & $\begin{array}{l}\text { Germany (Saxony), River } \\
415 \text { companies, Tl } \\
\text { No specific theory }\end{array}$ & $\begin{array}{l}\text { RP: Awareness, Likelihood } \\
\text { BV: Mitigation, Preparedness, Insurance } \\
\text { OIV: Experience, Length of time at the location }\end{array}$ & $\begin{array}{l}\text { The flaws of the Elbe flood-warning system are demonstrated by the companies' low preparedness and } \\
\text { precaution during the } 2002 \text { flood. The potential for more precautionary measures is highlighted. }\end{array}$ \\
\hline $\begin{array}{l}\text { Kreibich et al., } \\
2009(27)\end{array}$ & $\begin{array}{l}\text { Germany (Dresden), Groundwater } \\
605 \text { households, TI } \\
\text { No specific theory }\end{array}$ & $\begin{array}{l}\text { RP: Affect } \\
\text { BV: Mitigation, Preparedness } \\
\text { OIV: Experience, Protection responsibility }\end{array}$ & $\begin{array}{l}\text { The study reveals that hardly anybody is concerned about the risk of groundwater flooding. The } \\
\text { interviewees thought that public authorities, and not themselves, should be mainly responsible for } \\
\text { preparedness and emergency response. }\end{array}$ \\
\hline $\begin{array}{l}\text { Lara et al., } \\
2010(43)\end{array}$ & $\begin{array}{l}\text { Spain (Costa Brava), Flood (n.s.) } \\
285 \text { (FI) }+26 \text { (FG) residents } \\
\text { No specific theory }\end{array}$ & $\begin{array}{l}\text { RP: Impact, Cause } \\
\text { OIV: Experience, Temporary versus permanent residents, Public } \\
\text { participation }\end{array}$ & $\begin{array}{l}\text { The degree of social involvement in the local community is related to flood awareness and the } \\
\text { willingness to take actions. }\end{array}$ \\
\hline $\begin{array}{l}\text { Lave \& Lave, } \\
\text { 1991(83) }\end{array}$ & $\begin{array}{l}\text { USA (Pennsylvania), River / Flash } \\
22 \text { flood-plain residents, FI } \\
\text { Mental model }\end{array}$ & $\begin{array}{l}\text { RP: Awareness, Cause } \\
\text { BV: Insurance } \\
\text { OIV: Experience, Protection responsibility, Knowledge of mitigation } \\
\text { actions }\end{array}$ & $\begin{array}{l}\text { In general, there seems to be little knowledge of flood hazards among the public, nor is there interest in } \\
\text { buying flood insurance. Little effective risk communication is regarded an essential factor in this. }\end{array}$ \\
\hline $\begin{array}{l}\text { Lin et al., } \\
2008^{(31)}\end{array}$ & $\begin{array}{l}\text { Taiwan, Flood (n.s.) (+) } \\
1340 \text { households, II } \\
\text { Psychometric Paradigm }\end{array}$ & $\begin{array}{l}\text { RP: Likelihood, Dread, Control, Severity of consequences, } \\
\text { Knowledge of mitigation actions } \\
\text { BV: Mitigation, Insurance } \\
\text { OIV: Experience, Trust in risk management and communication } \\
\text { sources, Vulnerability }\end{array}$ & $\begin{array}{l}\text { (1) Flood victims seem to be less willing to adopt risk mitigation measures than the general public; (2) } \\
\text { trust, risk perception and socio-economic status are positive predictors for mitigation intentions, whereas } \\
\text { vulnerability is a negative predictor; and (3) psychological variables are stronger predictors for mitigation } \\
\text { intentions than socio-economic variables. }\end{array}$ \\
\hline $\begin{array}{l}\text { Lindell \& } \\
\text { Hwang, } \\
2008^{(34)}\end{array}$ & $\begin{array}{l}\text { USA (Texas), Flood (n.s.) (+) } \\
321 \text { households, MQ } \\
\text { Protective Action Decision Model }\end{array}$ & $\begin{array}{l}\text { RP: Perceived personal risk } \\
\text { BV: Mitigation } \\
\text { OIV: Experience, Tenure expectations, Distance from risk source, } \\
\text { Demographics }\end{array}$ & $\begin{array}{l}\text { The PADM, which proposes a causal chain from hazard proximity through hazard experience and } \\
\text { perceived personal risk to expectations of continued residence and adoption of hazard adjustments, is } \\
\text { largely supported. The mediating effects of hazard experience and perceived risk are found to be partial } \\
\text { rather than complete. }\end{array}$ \\
\hline $\begin{array}{l}\text { Lopez- } \\
\text { Marrero, } \\
2010(91)\end{array}$ & $\begin{array}{l}\text { Puerto Rico (Fajardo valley), River } \\
36 \text { households, FI } \\
\text { No specific theory }\end{array}$ & $\begin{array}{l}\text { RP: Likelihood, Impact } \\
\text { BV: Mitigation, Preparedness } \\
\text { OIV: Experience, Knowledge, Trust in flood protection }\end{array}$ & $\begin{array}{l}\text { Access to resources - including material, economic, and human resources - facilitates living with floods. } \\
\text { Together with cognitive factors, access to resources is an important determinant of adaptive capacity. }\end{array}$ \\
\hline $\begin{array}{l}\text { Lopez-Marrero } \\
\text { \& Yarnal, } \\
\text { 2010(44) }\end{array}$ & $\begin{array}{l}\text { Puerto Rico (Fajardo val.), River }(+) \\
56 \text { households, FI } \\
\text { No specific theory }\end{array}$ & $\begin{array}{l}\text { RP: Affect, Likelihood, Impact } \\
\text { OIV: Risk area }\end{array}$ & $\begin{array}{l}\text { In the Fajardo valley (Puerto Rico), floods are perceived as realistic risks, but these are not the most } \\
\text { important, nor the most severe risks in the people's lives. It is argued that flood management and } \\
\text { adaption strategies should consider these facts. }\end{array}$ \\
\hline
\end{tabular}




\begin{tabular}{|c|c|c|c|}
\hline $\begin{array}{l}\text { Author(s), } \\
\text { Year }\end{array}$ & $\begin{array}{l}\text { Research design } \\
\text { [Country, Flood type } \\
\text { Respondents, Survey delivery method, } \\
\text { Theory] }\end{array}$ & $\begin{array}{l}\text { Research variables } \\
{[\text { [Risk perception (RP) }} \\
\text { Behavioral variables (BV) } \\
\text { Other important variables (OIV] }\end{array}$ & Key findings \\
\hline $\begin{array}{l}\text { Martens et al., } \\
\text { 2009(58) }\end{array}$ & $\begin{array}{l}\text { Germany (Bremen), Flood (n.s.) } \\
589 \text { (TI) + } 242 \text { (OQ) residents } \\
\text { Motivation Intention Volition Model }\end{array}$ & $\begin{array}{l}\text { RP: Impact } \\
\text { BV: Mitigation, Preparedness } \\
\text { OIV: Protection responsibility }\end{array}$ & $\begin{array}{l}\text { A prototype of a computer-based information system is described that can produce and pass on tailored } \\
\text { risk information. Ideally, such an approach considers the social diversity of subpopulations. Social } \\
\text { vulnerability is the crucial concept for understanding the distribution of resources and capacities among } \\
\text { different social groups. }\end{array}$ \\
\hline $\begin{array}{l}\text { McEwen et al., } \\
2002^{(84)}\end{array}$ & $\begin{array}{l}\text { UK (Midlands), River } \\
21 \text { caravan park managers }(F I)+17 \\
\text { residents }(F I)+16 \text { wardens (MQ) } \\
\text { No specific theory }\end{array}$ & $\begin{array}{l}\text { RP: Awareness } \\
\text { BV: Mitigation, Insurance } \\
\text { OIV: Experience }\end{array}$ & $\begin{array}{l}\text { It is recommended that owners/managers at existing caravan parks at flood risk be legally required to } \\
\text { check on the flood risk, to draw up effective flood-action plans, to communicate this information to } \\
\text { prospective park users, and to consider flood risk in park design. }\end{array}$ \\
\hline $\begin{array}{l}\text { Miceli et al., } \\
2008(67)\end{array}$ & $\begin{array}{l}\text { Italy (Aosta Valley), Flood (n.s.) } \\
407 \text { adults, TI } \\
\text { Risk-as-feelings }\end{array}$ & $\begin{array}{l}\text { RP: Likelihood, Impact, Affect } \\
\text { BV: Mitigation, Preparedness } \\
\text { OIV: Experience, Distance from nearest water course, } \\
\text { Demographics }\end{array}$ & $\begin{array}{l}\text { The general preparedness level for future flood disaster seems high, and is positively correlated with } \\
\text { risk perception and feelings of worry. No significant relation is found between likelihood judgments and } \\
\text { adoption of protective behaviors. }\end{array}$ \\
\hline $\begin{array}{l}\text { Olcina Cantos } \\
\text { et al., 2010(88) }\end{array}$ & $\begin{array}{l}\text { Spain (Alicante), Flood (n.s.) } \\
85 \text { residents, } Q \text { (n.s.) } \\
\text { No specific theory }\end{array}$ & $\begin{array}{l}\text { RP: Awareness, Impact } \\
\text { BV: Mitigation, Insurance } \\
\text { OIV: Experience, Risk area, Permanent versus seasonal residents }\end{array}$ & $\begin{array}{l}\text { There is a lack of awareness among the Alicante population regarding flood risks. This finding is more } \\
\text { noticeable among seasonal inhabitants or residents who have only recently moved into the area. }\end{array}$ \\
\hline $\begin{array}{l}\text { Ologunorisa \& } \\
\text { Adeyemo, } \\
\text { 2005(85) }\end{array}$ & $\begin{array}{l}\text { Nigeria (Niger Delta), River } \\
432 \text { residents, Q (n.s.) } \\
\text { No specific theory }\end{array}$ & $\begin{array}{l}\text { RP: Likelihood, Impact, Cause } \\
\text { BV: Mitigation, Evacuation } \\
\text { OIV: Experience }\end{array}$ & $\begin{array}{l}\text { The public's knowledge and concern regarding flood risks is described. Environmental education and } \\
\text { mass media are seen as measures to improve flood control in the region and motivate community } \\
\text { efforts. }\end{array}$ \\
\hline $\begin{array}{l}\text { Pagneux et al., } \\
\text { 2011(194) }\end{array}$ & $\begin{array}{l}\text { Iceland, Flash } \\
112 \text { residents, FI } \\
\text { No specific theory }\end{array}$ & $\begin{array}{l}\text { RP: Awareness, Affect, Likelihood, Impact } \\
\text { OIV: Experience, Risk area, Length of residence }\end{array}$ & $\begin{array}{l}\text { (1) Among the public, there is poor awareness and little worry about historical inundations in the area; } \\
\text { (2) previous flood experience is the most effective source of knowledge; and (3) awareness, risk } \\
\text { estimation, and worry are not correlated. }\end{array}$ \\
\hline $\begin{array}{l}\text { Raaijmakers et } \\
\text { al., 2008(49) }\end{array}$ & $\begin{array}{l}\text { Spain (Ebro Delta), Coastal } \\
\text {-, FI } \\
\text { Psychometric Paradigm }\end{array}$ & $\begin{array}{l}\text { RP: Awareness, Affect } \\
\text { BV: Prepardness }\end{array}$ & $\begin{array}{l}\text { By using a spatial multi-criteria analysis, risk awareness, worry and preparedness are employed as } \\
\text { trade-offs for a set of scenarios. Such "risk profiles" can be useful for policy makers. }\end{array}$ \\
\hline $\begin{array}{l}\text { Ruin et al., } \\
2007^{(92)}\end{array}$ & $\begin{array}{l}\text { France (Gard), Flash } \\
200 \text { motorists, FI } \\
\text { No specific theory }\end{array}$ & $\begin{array}{l}\text { RP: Awareness, Impact } \\
\text { OIV: Experience, Travel behavior, Length of residence, Knowledge } \\
\text { about protective actions }\end{array}$ & $\begin{array}{l}\text { Cognitive mapping combined with GIS data is used to assess motorists' flash flood risk perception on } \\
\text { their daily itineraries. The analysis of } 200 \text { mental maps provides planners with information on vulnerable } \\
\text { areas (high-risk/low-risk perception). }\end{array}$ \\
\hline $\begin{array}{l}\text { Siegrist \& } \\
\text { Gutscher, } \\
2006^{(3)}\end{array}$ & $\begin{array}{l}\text { Switzerland, Flood (n.s.) } \\
1213 \text { residents, MQ } \\
\text { No specific theory }\end{array}$ & $\begin{array}{l}\text { RP: Impact } \\
\text { BV: Mitigation } \\
\text { OIV: Experience, Risk area }\end{array}$ & $\begin{array}{l}\text { A correlation is found between the respondents' risk perceptions and the experts' risk assessments. In } \\
\text { line with the availability heuristic, previous flood experience is positively correlated with risk perception. }\end{array}$ \\
\hline $\begin{array}{l}\text { Siegrist \& } \\
\text { Gutscher, } \\
\text { 2008(68) }\end{array}$ & $\begin{array}{l}\text { Switzerland, Flood (n.s.) } \\
201 \text { residents, Fl } \\
\text { Affect heuristic }\end{array}$ & $\begin{array}{l}\text { RP: Affect } \\
\text { BV: Mitigation, Preparedness } \\
\text { OIV: Experience }\end{array}$ & $\begin{array}{l}\text { It is demonstrated that people who are not affected strongly underestimate the negative affect } \\
\text { associated with a flood. Hence, risk communication must not focus only on technical aspects, but also } \\
\text { on affect (e.g., help people to envisage the negative emotional consequences of natural disasters). }\end{array}$ \\
\hline $\begin{array}{l}\text { Takao et al., } \\
2004(86)\end{array}$ & $\begin{array}{l}\text { Japan (Nagoya City), Flood (n.s.) } \\
2051 \text { residents, MQ } \\
\text { No specific theory }\end{array}$ & $\begin{array}{l}\text { RP: Likelihood, Affect } \\
\text { BV: Preparedness, Insurance } \\
\text { OIV: Experience }\end{array}$ & $\begin{array}{l}\text { Flood preparedness depends on homeownership, fear of flooding, and the amount of damage from } \\
\text { previous floods, rather than on previous experience with, and anticipation of, floods. }\end{array}$ \\
\hline
\end{tabular}




\begin{tabular}{|c|c|c|c|}
\hline $\begin{array}{l}\text { Author(s), } \\
\text { Year }\end{array}$ & $\begin{array}{l}\text { Research design } \\
\text { [Country, Flood type } \\
\text { Respondents, Survey delivery method, } \\
\text { Theory] }\end{array}$ & $\begin{array}{l}\text { Research variables } \\
\text { [Risk perception (RP) } \\
\text { Behavioral variables (BV) } \\
\text { Other important variables (OIV)] }\end{array}$ & Key findings \\
\hline $\begin{array}{l}\text { Terpstra, } \\
2011(69)\end{array}$ & $\begin{array}{l}\text { The Netherlands, Flood (n.s.) } \\
472+428+861 \text { residents, } O Q \\
\text { Affect heuristic }\end{array}$ & $\begin{array}{l}\text { RP: Likelihood, Impact, Affect } \\
\text { BV: Preparedness } \\
\text { OIV: Experience, Demographics }\end{array}$ & $\begin{array}{l}\text { Both cognitive and affective mechanisms influence citizens' preparedness intentions. In line with the } \\
\text { affect heuristic, both positive (e.g., solidarity) and negative emotions (e.g., powerlessness) are related to } \\
\text { previous flood-hazard experiences. }\end{array}$ \\
\hline $\begin{array}{l}\text { Terpstra et al., } \\
20066^{(45)}\end{array}$ & $\begin{array}{l}\text { The Netherlands, River / Coastal } \\
49 \text { residents (MQ) + } 14 \text { (FG) } \\
\text { Psychometric Paradigm }\end{array}$ & $\begin{array}{l}\text { RP: Increasing risk, Dread, Knowledge, Controllability, Number of } \\
\text { people exposed, Risk-benefits, Trust }\end{array}$ & $\begin{array}{l}\text { A factor analysis of } 49 \text { questionnaires resulted in the identification of eight flooding factors and three } \\
\text { water-nuisance factors. Similar to the perception of external safety risks, "dread" is deemed the most } \\
\text { important concept binding different characteristics. }\end{array}$ \\
\hline $\begin{array}{l}\text { Terpstra \& } \\
\text { Gutteling, } \\
\text { 2008(5) }\end{array}$ & $\begin{array}{l}\text { The Netherlands (Friesland), Coastal } \\
658 \text { residents }(\mathrm{OQ}) \\
\text { No specific theory }\end{array}$ & $\begin{array}{l}\text { RP: Likelihood, Affect, Impact } \\
\text { BV: Mitigation, Preparedness } \\
\text { OIV: Protection responsibility, Trust in flood protection, } \\
\text { Demographics }\end{array}$ & $\begin{array}{l}\text { While } 73 \% \text { of the respondents regard the government as primarily responsible for flood protection, } \\
\text { about } 50 \% \text { view disaster preparedness as an equal responsibility between themselves and the } \\
\text { government. A substantial part of the public may thus have an open attitude to communication about } \\
\text { disaster preparation measures. }\end{array}$ \\
\hline $\begin{array}{l}\text { Terpstra et al., } \\
2009^{(37)}\end{array}$ & $\begin{array}{l}\text { The Netherlands, Coastal } \\
\text { Quasi-experimental: } 80 \text { res. (MQ/FG) } \\
\text { Psychometric Paradigm, Persuasive } \\
\text { Arguments Theory }\end{array}$ & $\begin{array}{l}\text { RP: Increasing risk, Dread, Known to Science/Exposed, } \\
\text { Controllability, Trust, Public support } \\
\text { OIV: Demographics }\end{array}$ & $\begin{array}{l}\text { Risk perception is examined by both conventional tests of the mean differences and tests for attitude } \\
\text { polarization. It is suggested that attitude polarization might cause people to confirm their preexisting } \\
\text { (hazard) beliefs, which might have important implications for risk communication. }\end{array}$ \\
\hline $\begin{array}{l}\text { Thieken et al., } \\
2006^{(87)}\end{array}$ & $\begin{array}{l}\text { Germany (Elbe catchment), River } \\
1248 \text { households, TI } \\
\text { No specific theory }\end{array}$ & $\begin{array}{l}\text { RP: Awareness, Likelihood, Impact } \\
\text { BV: Mitigation, Preparedness, Insurance, Information seeking } \\
\text { OIV: Experience }\end{array}$ & $\begin{array}{l}\text { Flood-loss compensation, risk awareness, and mitigation are compared between insured and uninsured } \\
\text { private households. Insured households received loss compensation earlier and showed slightly better } \\
\text { risk awareness and mitigation strategies. }\end{array}$ \\
\hline $\begin{array}{l}\text { Thieken et al., } \\
\text { 2007(46) }\end{array}$ & $\begin{array}{l}\text { Germany, River / Flash } \\
1697 \text { households, TI } \\
\text { No specific theory }\end{array}$ & $\begin{array}{l}\text { RP: Awareness, Likelihood, Impact } \\
\text { BV: Mitigation, Preparedness, Insurance } \\
\text { OIV: Experience, Risk Area, Perceived quality of the building }\end{array}$ & $\begin{array}{l}\text { Knowledge about self-protection, residents' } ₫ \text { lomeownership, and household size are found to influence } \\
\text { the extent and type of private precautions taken, as well as the residents' ability to perform mitigation } \\
\text { measures. }\end{array}$ \\
\hline $\begin{array}{l}\text { Wagner, } \\
2007^{(32)}\end{array}$ & $\begin{array}{l}\text { Germany (Bavarian Alps), Flash (+) } \\
169 \text { residents }(\mathrm{FI})+1205(\mathrm{TI}) \\
\text { Mental model }\end{array}$ & $\begin{array}{l}\text { RP: Awareness, Affect, Cause } \\
\text { BV: Non-protective response } \\
\text { OIV: Experience, Demographics }\end{array}$ & $\begin{array}{l}\text { It is shown that mental models concerning flash floods are much better developed than those for } \\
\text { landslides because the key physical processes for flash floods are easier for the general public to } \\
\text { recognize and understand. }\end{array}$ \\
\hline $\begin{array}{l}\text { Wong \& Zhao, } \\
\text { 2001(54) }\end{array}$ & $\begin{array}{l}\text { China (Beijing catchment), River } \\
52 \text { households, } \mathrm{Fl} \\
\text { No specific theory }\end{array}$ & $\begin{array}{l}\text { RP: Awareness, Impact } \\
\text { BV: Mitigation } \\
\text { OIV: Experience, Trust in flood risk management, Responsibility }\end{array}$ & $\begin{array}{l}\text { With respect to the } 1994 \text { floods in the Beijing area (China), flood victims are skeptical about future large } \\
\text { flood-prevention structures. Instead, they are willing to "live with" floods, and have adopted functional } \\
\text { adjustments to mitigate flood impacts. }\end{array}$ \\
\hline $\begin{array}{l}\text { Zaalberg et al., } \\
\text { 2009(50) }\end{array}$ & $\begin{array}{l}\text { The Netherlands, River } \\
516 \text { residents, MQ } \\
\text { Protection Motivation Theory }\end{array}$ & $\begin{array}{l}\text { RP: Affect, Likelihood, Impact } \\
\text { BV: Mitigation, Preparedness, Non-protective responses } \\
\text { OIV: Experience, Demographics }\end{array}$ & $\begin{array}{l}\text { Using SEM, previous flood experience is found to be associated with social support, worry, vulnerability, } \\
\text { perceived flood consequences, and intentions to take adaptive actions. Such knowledge may prove } \\
\text { helpful in developing interventions to inform residents how to act effectively in case of an imminent } \\
\text { flood. }\end{array}$ \\
\hline $\begin{array}{l}\text { Zhai \& Ikeda, } \\
2006(80)\end{array}$ & $\begin{array}{l}\text { Japan (Sanjyo, Fukui and Toyo'oka) } \\
\text { Flood (n.s.) } \\
1259 \text { residents, MQ } \\
\text { Contingent Valuation Method }\end{array}$ & $\begin{array}{l}\text { RP: Flood risk acceptability } \\
\text { BV: Evacuation } \\
\text { OIV: Experience, Risk Area, Demographics }\end{array}$ & $\begin{array}{l}\text { The economic value of evacuation (willingness to pay - WTP) can be taken into consideration in the } \\
\text { risk-assessment process in order to evaluate the efficiency of risk-reduction measures. Flood-risk } \\
\text { acceptability and home ownership are two major statistically significantly determinants of the WTP. }\end{array}$ \\
\hline $\begin{array}{l}\text { Zhai et al., } \\
\text { 2006(79) }\end{array}$ & $\begin{array}{l}\text { Japan (Toki-Shonai basin), River } \\
428 \text { households, MQ } \\
\text { Contingent Valuation Method }\end{array}$ & $\begin{array}{l}\text { RP: Likelihood, Impact } \\
\text { BV: Preparedness } \\
\text { OIV: Experience, Risk Area, Distance from river, Demographics }\end{array}$ & $\begin{array}{l}\text { WTP for flood-control measures may increase with per capita income, individual preparedness, } \\
\text { experience with flooding, and/or flood risk perception, but may decrease with distance from a river, } \\
\text { acceptability of flood risk, provision of environmental information, and/or risk perception of non-flood } \\
\text { hazards. }\end{array}$ \\
\hline
\end{tabular}




\begin{tabular}{|c|c|c|c|}
\hline $\begin{array}{l}\text { Author(s), } \\
\text { Year }\end{array}$ & $\begin{array}{l}\text { Research design } \\
\text { [Country, Flood type } \\
\text { Respondents, Survey delivery method, } \\
\text { Theory] }\end{array}$ & $\begin{array}{l}\text { Research variables } \\
\text { [Risk perception (RP) } \\
\text { Behavioral variables (BV) } \\
\text { Other important variables (OIV)] }\end{array}$ & Key findings \\
\hline $\begin{array}{l}\text { Zhai \& Ikeda, } \\
\text { 2008(60) }\end{array}$ & $\begin{array}{l}\text { Japan (Toki-Shonai basin), River } \\
428 \text { households, MQ } \\
\text { Rational Action Paradigm } \\
\end{array}$ & $\begin{array}{l}\text { RP: Likelihood, Impact } \\
\text { BV: Preparedness, Insurance } \\
\text { OIV: Experience, Risk Area, Distance from river, Demographics }\end{array}$ & $\begin{array}{l}\text { Flood-risk acceptability is associated with a multi-risk context: whether a flood risk is accepted depends } \\
\text { not only on the factors of the flood hazard itself but also on other types of risks. }\end{array}$ \\
\hline $\begin{array}{l}\text { Zhang et al., } \\
2010^{(93)}\end{array}$ & $\begin{array}{l}\text { USA (Texas), Coastal }(+) \\
321 \text { residents, MQ } \\
\text { No specific theory }\end{array}$ & $\begin{array}{l}\text { RP: Impact } \\
\text { OIV: Hazard proximity, Demographics }\end{array}$ & $\begin{array}{l}\text { Risk perception is found to be a mediating factor between hazard proximity and property value, although } \\
\text { the relation might be partial rather than complete. Hazard proximity can act as a potential risk and an } \\
\text { environmental amenity at the same time. These two perceptions operate in opposite directions when } \\
\text { affecting housing value. }\end{array}$ \\
\hline
\end{tabular}

$\mathrm{MQ}=$ mail questionnaire, $\mathrm{OQ}=$ online questionnaire, $\mathrm{FG}=$ focus group, $\mathrm{FI}$ = face-to-face interview, $\mathrm{TI}$ = telephone interview

n.s. = not specified, ' + ' = other hazards (not flood)

All studies performed cross-sectional surveys unless stated otherwise. 


\section{ACKNOWLEDGEMENTS}

Financial support for this work was provided by Research Foundation - Flanders. The authors would like to thank the anonymous referees for their valuable comments and suggestions on earlier drafts of this paper.

\section{REFERENCES}

1. Smith K, Petley DN. Environmental Hazards. Assessing risk and reducing disaster. London: Routledge; 2009.

2. IPCC. Climate Change 2007: impacts, adaptation and vulnerability. In: ML Parry; OF Canziani; JP Palutikof et al., editors, translator and editor Contribution Group II to the fourth assessment report of the intergovernmental panel on climate change. Cambridge, UK: Cambridge University Press; 2007.

3. Siegrist M, Gutscher H. Flooding risks: A comparison of lay people's perceptions and expert's assessments in Switzerland. Risk Analysis, 2006; 26 (4):971-979.

4. Merz B, Kreibich H, Schwarze R, Thieken A. Review article "Assessment of economic flood damage". Natural Hazards and Earth System Sciences, 2010; 10 (8):1697-1724.

5. Terpstra T, Gutteling JM. Households' perceived responsibilities in flood risk management in the Netherlands. International Journal of Water Resources Development, 2008; 24 (4):555-565.

6. Botzen WJW, Aerts JCJH, van den Bergh JCJM. Dependence of flood risk perceptions on socioeconomic and objective risk factors. Water Resources Research, 2009; 45 (10):15.

7. Figueiredo E, Valente S, Coelho C, Pinho L. Coping with risk: analysis on the importance of integrating social perceptions on flood risk into management mechanisms - the case of the municipality of Agueda, Portugal. Journal of Risk Research, 2009; 12 (5):581-602.

8. Renn O. White Paper on Risk Governance: Towards an Integrative Approach. Geneva, Switzerland: International Risk Governance Council (IRGC). 
9. Fischhoff B. Risk Perception and Communication Unplugged - 20 Years of Process. Risk Analysis, 1995; 15 (2):137-145.

10. Boholm A. Comparative studies of risk perception: a review of twenty years of research. Journal of Risk Research, 1998; 1 (2):135-163.

11. Bier VM. On the state of the art: risk communication to the public. Reliability Engineering \& System Safety, 2001; 71 (2):139-150.

12. White GF. Human adjustment to floods - a geographical approach to the flood problem in the United States. Chicago: University of Chicago; 1945.

13. Brilly M, Polic M. Public perception of flood risks, flood forecasting and mitigation. Natural Hazards and Earth System Sciences, 2005; 5 (3):345-355.

14. Bird DK. The use of questionnaires for acquiring information on public perception of natural hazards and risk mitigation - a review of current knowledge and practice. Natural Hazards and Earth System Sciences, 2009; 9 (4):1307-1325.

15. Starr C. Social benefit versus technological risk. Science, 1969; 165 (3899):1232-1238.

16. Sjöberg L, Moen B, Rundmo T. Explaining risk perception. An evaluation of the psychometric paradigm in risk perception research. Trondheim: Norwegian University of Science and Technology, Department of Psychology.

17. Craye M, Goorden L, Van Gelder S, Vandenabeele J. Milieu en gezondheid: naar een adequate dialoog tussen overheid, bevolking en wetenschapStudiecentrum Technologie Energie en Milieu (STEM), Antwerp University.

18. Covello VT, von Winterfeldt D, Slovic P. Risk communication: a review of literature. Risk Abstracts, 1986; 3:171-182.

19. Trettin L, Musham C. Is trust a realistic goal of environmental risk communication? Environment and Behavior, 2000; 32 (3):410-426.

20. Boholm A. New perspectives on risk communication: uncertainty in a complex society. Journal of Risk Research, 2008; 11 (1-2):1-3.

21. Basic F. Geographic Visualisation Tools for Communicating Flood Risks to The Public. Melbourne, Australia: RMIT University; 2009. 230 p. 
22. Renn O. Three decades of risk research: Accomplishments and new challenges. Journal of Risk Research, 1998; 1 (1):49-71.

23. Habermans J. The theory of communication action. Cambridge: Beacon Press; 1985.

24. Petts J. Public engagement to build trust: false hopes? Journal of Risk Research, 2008; 11 (6):821-835.

25. Pidgeon NF. The Psychology of Risk. In: DI Blockley, editor, translator and editor Engineering Safety. Maidenhead: McGraw-Hill; 1992; p. 167-185.

26. Krasovskaia I, Gottschalk L, Ibrekk AS, Berg H. Perception of flood hazard in countries of the North Sea region of Europe. Nordic Hydrology, 2007; 38 (4-5):387-399.

27. Kreibich H, Thieken AH, Grunenberg H, Ullrich K, Sommer T. Extent, perception and mitigation of damage due to high groundwater levels in the city of Dresden, Germany. Natural Hazards and Earth System Sciences, 2009; 9 (4):1247-1258.

28. Arthur S, Crow H, Karikas N. Including public perception data in the evaluation of the consequences of sewerage derived urban flooding. Water Science and Technology, 2009; 60 (1):231242.

29. Heitz C, Spaeter S, Auzet AV, Glatron S. Local stakeholders' perception of muddy flood risk and implications for management approaches: A case study in Alsace (France). Land Use Policy, $2009 ; 26$ (2):443-451.

30. Ho MC, Shaw D, Lin SY, Chiu YC. How do disaster characteristics influence risk perception? Risk Analysis, 2008; 28 (3):635-643.

31. Lin SY, Shaw DG, Ho MC. Why are flood and landslide victims less willing to take mitigation measures than the public? Natural Hazards, 2008; 44 (2):305-314.

32. Wagner K. Mental models of flash floods and landslides. Risk Analysis, 2007; 27 (3):671682.

33. Ge Y, Xu W, Gu Z-H, Zhang Y-C, Chen L. Risk perception and hazard mitigation in the Yangtze River Delta region, China. Natural Hazards, 2010:1-16.

34. Lindell MK, Hwang SN. Households' perceived personal risk and responses in a multihazard environment. Risk Analysis, 2008; 28 (2):539-556. 
35. Saunders M, Lewis P, Thornhill A. Research methods for business students. United Kingdom: Pearson Education Limited; 2006. 599 p.

36. Keller C, Siegrist M, Gutscher $\mathrm{H}$. The role of the affect and availability heuristics in risk communication. Risk Analysis, 2006; 26 (3):631-639.

37. Terpstra T, Lindell MK, Gutteling JM. Does Communicating (Flood) Risk Affect (Flood) Risk Perceptions? Results of a Quasi-Experimental Study. Risk Analysis, 2009; 29 (8):1141-1155.

38. Lindell MK, Perry RW. Household adjustment to earthquake hazard - A review of research. Environment and Behavior, 2000; 32 (4):461-501.

39. Ali AMS. September 2004 flood event in southwestern Bangladesh: A study of its nature, causes, and human perception and adjustments to a new hazard. Natural Hazards, 2007; 40 (1):89111.

40. Armas I, Avram E. Perception of flood risk in Danube Delta, Romania. Natural Hazards, 2009; 50 (2):269-287.

41. Benight CC, Gruntfest EC, Hayden M, Barnes L. Trauma and short-fuse weather warning perceptions. Environmental Hazards, 2007; 7 (3):220-226.

42. Hung HC. The attitude towards flood insurance purchase when respondents' preferences are uncertain: a fuzzy approach. Journal of Risk Research, 2009; 12 (2):239-258.

43. Lara A, Sauri D, Ribas A, Pavon D. Social perceptions of floods and flood management in a Mediterranean area (Costa Brava, Spain). Natural Hazards and Earth System Sciences, 2010; 10 (10):2081-2091.

44. Lopez-Marrero T, Yarnal B. Putting adaptive capacity into the context of people's lives: a case study of two flood-prone communities in Puerto Rico. Natural Hazards, 2010; 52 (2):277-297.

45. Terpstra T, Gutteling JM, Geldof GD, Kappe LJ. The perception of flood risk and water nuisance. Water Science and Technology, 2006; 54 (6-7):431-439.

46. Thieken AH, Kreibich H, Muller M, Merz B. Coping with floods: preparedness, response and recovery of flood-affected residents in Germany in 2002. Hydrological Sciences Journal-Journal Des Sciences Hydrologiques, 2007; 52 (5):1016-1037. 
47. Kreibich H, Muller M, Thieken AH, Merz B. Flood precaution of companies and their ability to cope with the flood in August 2002 in Saxony, Germany. Water Resources Research, 2007; 43 (3):-

48. Kellens W, Zaalberg R, Neutens T, Vanneuville W, De Maeyer P. An Analysis of the Public Perception of Flood Risk on the Belgian Coast. Risk Analysis, 2011; 31 (7):1055-1068.

49. Raaijmakers R, Krywkow J, van der Veen A. Flood risk perceptions and spatial multi-criteria analysis: an exploratory research for hazard mitigation. Natural Hazards, 2008; 46 (3):307-322.

50. Zaalberg R, Midden C, Meijnders A, McCalley T. Prevention, Adaptation, and Threat Denial: Flooding Experiences in the Netherlands. Risk Analysis, 2009; 29 (12):1759-1778.

51. Botzen WJW, Aerts JCJH, van den Bergh JCJM. Willingness of homeowners to mitigate climate risk through insurance. Ecological Economics, 2009; 68 (8-9):2265-2277.

52. Krasovskaia I. Perception of the risk of flooding: the case of the 1995 flood in Norway. Hydrological Sciences Journal-Journal Des Sciences Hydrologiques, 2001; 46 (6):855-868.

53. Horney JA, MacDonald PDM, Van Willigen M, Berke PR, Kaufman JS. Individual Actual or Perceived Property Flood Risk: Did it Predict Evacuation from Hurricane Isabel in North Carolina, 2003? Risk Analysis, 2010; 30 (3):501-511.

54. Wong KK, Zhao XB. Living with floods: victims' perceptions in Beijiang, Guangdong, China. Area, 2001; 33 (2):190-201.

55. Harries T. Feeling secure or being secure? Why it can seem better not to protect yourself against a natural hazard. Health Risk \& Society, 2008; 10 (5):479-490.

56. Whitmarsh L. Are flood victims more concerned about climate change than other people? The role of direct experience in risk perception and behavioural response. Journal of Risk Research, 2008; $11(3): 351-374$.

57. Correia Fn, Fordham M, Saraiva MdG, Bernardo F. Flood Hazard Assessment and Management: Interface with the Public Water Resources Management, 1998; 12 (3):209-227.

58. Martens T, Garrelts H, Grunenberg H, Lange H. Taking the heterogeneity of citizens into account: flood risk communication in coastal cities - a case study of Bremen. Natural Hazards and Earth System Sciences, 2009; 9 (6):1931-1940. 
59. Knocke ET, Kolivras KN. Flash flood awareness in southwest Virginia. Risk Analysis, 2007; $27(1): 155-169$.

60. Zhai G, Ikeda S. Empirical analysis of Japanese flood risk acceptability within multi-risk context. Natural Hazards and Earth System Sciences, 2008; 8 (5):1049-1066.

61. Burningham K, Fielding J, Thrush D. 'It'll never happen to me': understanding public awareness of local flood risk. Disasters, 2008; 32 (2):216-238.

62. Alreck PL, Settle RB. The Survey Research Handbook. New York: McGraw-Hill; 2004. (3rd ed.).

63. Fischhoff B, Slovic P, Lichtenstein S, Read S, Combs B. How Safe is Safe Enough Psychometric Study of Attitudes towards Technological Risks and Benefits. Policy Sciences, 1978; 9 (2):127-152.

64. Slovic P. Perception of Risk. Science, 1987; 236 (4799):280-285.

65. Tversky A, Kahnemann D. Judgment Under Uncertainty: Heuristics and Biases. Science, $1974 ; 185: 1124-1131$.

66. Slovic P, Finucane ML, Peters E, MacGregor DG. Risk as analysis and risk as feelings: Some thoughts about affect, reason, risk, and rationality. Risk Analysis, 2004; 24 (2):311-322.

67. Miceli R, Sotgiu I, Settanni M. Disaster preparedness and perception of flood risk: A study in an alpine valley in Italy. Journal of Environmental Psychology, 2008; 28 (2):164-173.

68. Siegrist M, Gutscher H. Natural hazards and motivation for mitigation behavior: People cannot predict the affect evoked by a severe flood. Risk Analysis, 2008; 28 (3):771-778.

69. Terpstra T. Emotions, trust and perceived risk: Affective and cognitive routes to flood preparedness behavior. Risk Analysis, 2011; 31 (10):1658-1675.

70. Lindell MK, Perry RW. Communicating Environmental Risk in Multiethnic Communities. Thousand Oaks, CA: Sage Publications; 2004.

71. FEMA. A Nation Prepared.

72. ten Brinke WBM, Saeijs GEM, Helsloot I, van Alphen J. Safety chain approach in flood risk management. Proceedings of the Institution of Civil Engineers-Municipal Engineer, 2008; 161 (2):93102. 
73. Vroom VH. Work and Motivation. New York: Wiley; 1964.

74. Griffin RJ, Dunwoody S, Neuwirth K. Proposed model of the relationship of risk information seeking and processing to the development of preventive behaviors. Environmental Research, 1999; 80 (2):S230-S245.

75. Grothmann T, Reusswig F. People at risk of flooding: Why some residents take precautionary action while others do not. Natural Hazards, 2006; 38 (1-2):101-120.

76. Norman P, Boer H, Seydel ER. Protection Motivation Theory. In: P Norman; M Conner, editors, translator and editor Predicting Health Behaviour: Research and Practice with Social Cognition Models. Berkshire, England: Open University Press; 2005; p. 81-126.

77. Weinstein ND. Testing four competing theories of health-protective behavior. Health Psychology, 1993; 12 (4):324-333.

78. Griffin RJ, Yang Z, ter Huurne E, Boerner F, Ortiz S, Dunwoody S. After the flood - Anger, attribution, and the seeking of information. Science Communication, 2008; 29 (3):285-315.

79. Zhai GF, Sato T, Fukuzono T, Ikeda S, Yoshida K. Willingness to pay for flood risk reduction and its determinants in Japan. Journal of the American Water Resources Association, 2006; 42 (4):927-940.

80. Zhai GF, Ikeda S. Flood risk acceptability and economic value of evacuation. Risk Analysis, 2006; 26 (3):683-694.

81. Weyma A. Risk communication - A mental models approach. Journal of Risk Research, 2003; $6(1): 93-94$.

82. Visschers VHM, Meertens RM, Passchier WF, de Vries NK. How does the general public evaluate risk information? The impact of associations with other risks. Risk Analysis, 2007; 27 (3):715-727.

83. Lave TR, Lave LB. Public Perception of the Risks of Floods - Implications for Communication. Risk Analysis, 1991; 11 (2):255-267.

84. McEwen L, Hall T, Hunt J, Dempsey M, Harrison M. Flood warning, warning response and planning control issues associated with caravan parks: the April 1998 floods on the lower Avon floodplain, Midlands region, UK. Applied Geography, 2002; 22 (3):271-305. 
85. Ologunorisa T, Adeyemo A. Public Perception of Flood Hazard in the Niger Delta, Nigeria. The Environmentalist, 2005; 25 (1):39-45.

86. Takao K, Motoyoshi T, Sato T, Fukuzono T. Factors determining residents' preparedness for floods in modern megalopolises: the case of the Tokai flood disaster in Japan. Journal of Risk Research, 2004; 7 (7-8):775-787.

87. Thieken AH, Petrow T, Kreibich H, Merz B. Insurability and mitigation of flood losses in private households in Germany. Risk Analysis, 2006; 26 (2):383-395.

88. Olcina Cantos J, Hernandez Hernandez M, Rico Amoros AM, Martinez Ibarra E. Increased risk of flooding on the coast of Alicante (Region of Valencia, Spain). Natural Hazards and Earth System Sciences, 2010; 10 (11):2229-2234.

89. Devilliers GD, Maharaj R. Human Perceptions and Responses to Floods with Specific Reference to the 1987 Flood in the Mdloti River near Durban, South-Africa. Water Sa, 1994; 20 (1):913.

90. Bell HM, Tobin GA. Efficient and effective? The 100-year flood in the communication and perception of flood risk. Environmental Hazards, 2007; 7 (4):302-311.

91. Lopez-Marrero T. An integrative approach to study and promote natural hazards adaptive capacity: a case study of two flood-prone communities in Puerto Rico. Geographical Journal, 2010; 176:150-163.

92. Ruin I, Gaillard J-C, Lutoff C. How to get there? Assessing motorists' flash flood risk perception on daily itineraries. Environmental Hazards, 2007; 7 (3):235-244.

93. Zhang Y, Hwang SN, Lindell MK. Hazard Proximity or Risk Perception? Evaluating Effects of Natural and Technological Hazards on Housing Values. Environment and Behavior, 2010; 42 (5):597-624

94. Pagneux E, Gisladottir G, Jonsdottir S. Public perception of flood hazard and flood risk in Iceland: a case study in a watershed prone to ice-jam floods. Natural Hazards, 2011; 58 (1):269-287. 95. Halpern-Felsher BL, Millstein SG, Ellen JM, Adler NE, Tschann JM, Biehl M. The role of behavioral experience in judging risks. Health Psychology, 2001; 20 (2):120-126. 
96. Wilson C. Education and Risk. In: J Handmer; E Penning-Rowsell, editors, translator and editor Hazards and the Communication of Risk. Brookfield, Vt.: Gower; 1990; p. 53-68.

97. Peacock WG, Brody SD, Highfield W. Hurricane risk perceptions among Florida's single family homeowners. Landscape and Urban Planning, 2005; 73 (2-3):120-135.

98. Burn DH. Perceptions of flood risk: A case study of the Red River flood of 1997. Water Resources Research, 1999; 35 (11):3451-3458.

99. Griffin RJ, Neuwirth K, Dunwoody S, Giese J. Information sufficiency and risk communication. Media Psychology, 2004; 6 (1):23-61.

100. Weinstein ND, Nicolich M. Correct And Incorrect Interpretations Of Correlations Between Risk Perceptions And Risk Behaviors. Health Psychology, 1993; 12 (3):235-245.

101. Hagemeier-Klose M, Wagner K. Evaluation of flood hazard maps in print and web mapping services as information tools in flood risk communication. Natural Hazards and Earth System Sciences, 2009; 9 (2):563-574. 